University of Louisville

ThinkIR: The University of Louisville's Institutional Repository

Electronic Theses and Dissertations

$5-2017$

\title{
Student attitudes on social media and perception of instructor social media use.
}

Abi Mathew John

University of Louisville

Follow this and additional works at: https://ir.library.louisville.edu/etd

Part of the Communication Technology and New Media Commons, Mass Communication Commons, and the Social Media Commons

\section{Recommended Citation}

John, Abi Mathew, "Student attitudes on social media and perception of instructor social media use."

(2017). Electronic Theses and Dissertations. Paper 2647.

https://doi.org/10.18297/etd/2647

This Master's Thesis is brought to you for free and open access by ThinkIR: The University of Louisville's Institutional Repository. It has been accepted for inclusion in Electronic Theses and Dissertations by an authorized administrator of ThinkIR: The University of Louisville's Institutional Repository. This title appears here courtesy of the author, who has retained all other copyrights. For more information, please contact thinkir@louisville.edu. 
STUDENT ATTITUDES ON SOCIAL MEDIA AND PERCEPTION OF INSTRUCTOR SOCIAL MEDIA USE

\author{
By \\ Abi Mathew John \\ B.A., University of Louisville, 2015 \\ A Thesis \\ Submitted to the Faculty of the \\ College of Arts and Sciences of the University of Louisville \\ in Partial Fulfillment of the Requirements \\ for the Degree of \\ Master of Arts \\ in Communication \\ Department of Communication \\ University of Louisville \\ Louisville, Kentucky
}

May 2017 

STUDENT ATTITUDES ON SOCIAL MEDIA AND PERCEPTION OF INSTRUCTOR SOCIAL MEDIA USE

\section{By}

Abi Mathew John

B.A., University of Louisville, 2015

A Thesis Approved on

April 24, 2017

By the following Thesis Committee:

Karen Freberg

James Chisholm

Al Futrell 


\section{DEDICATION}

This thesis is dedicated to my family and friends, without whom this dream would not be reality. 


\section{ACKNOWLEDGEMENTS}

I would like to thank my thesis supervisor and professor, Dr. Karen Freberg, for her guidance, support, and constant encouragement. I would also like to thank my other committee members, Dr. Al Futrell and Dr. James Chisholm for their comments and assistance over the past year. I would like to express my gratitude to the Department of Communication and to every professor I've had the privilege to be educated under. I also express my gratitude to my brother and sister-in-law, Roshan and Rebecca John for providing me the emotional support I needed to persevere these past two years. Also, to my fellow cohorts, who made the struggles worth bearing and the victories worth rejoicing, you have my eternal gratitude. Finally, I want to express a special thanks to Professor Tammy Voigt, who got me started on this journey five years ago. 


\section{ABSTRACT \\ STUDENT ATTITUDES ON SOCIAL MEDIA AND PERCEPTION OF INSTRUCTOR SOCIAL MEDIA USE}

Abi M. John

March 24, 2017

The purpose of this study is to understand what student attitudes are toward using social media in the classroom and if those attitudes influenced how they perceive instructors using social media in the classroom. Implementing a mixed method approach, this study conducted focus groups to gain an in-depth understanding of what student attitudes were and why they held those ideas. A survey was then distributed to the students' in a Midwestern University to see if there was a relationship between students attitudes and their perceptions of instructors who use social media. Results showed that students do hold a positive attitude toward using social media if the participation was voluntary. The survey results showed only certain items (such as voluntariness and proficiency) moderately correlated with the perception of the instructor. Implications of the results as well as the limitations and potential for future research are discussed. 


\section{TABLE OF CONTENTS}

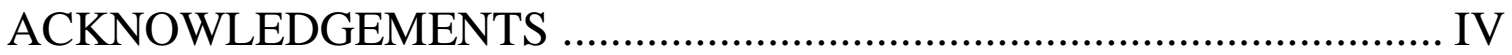

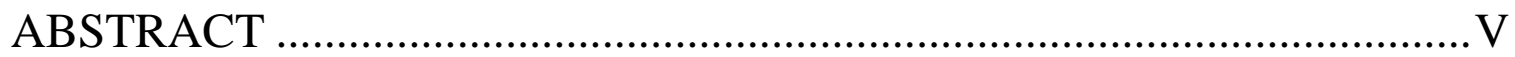

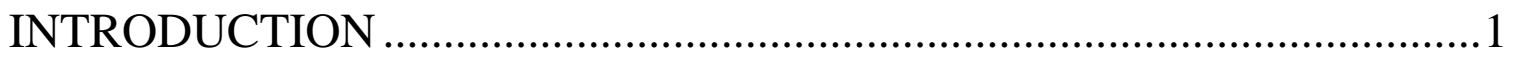

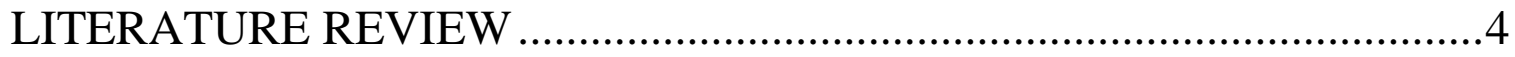

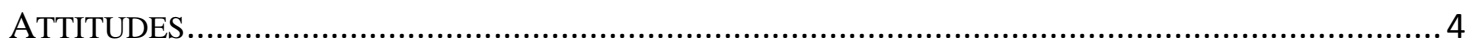

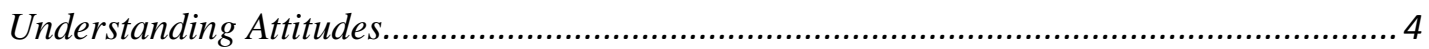

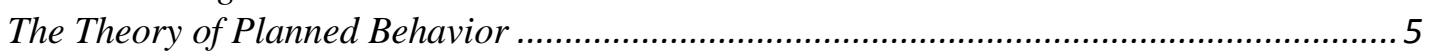

EDUCATION AND TECHNOLOGY ............................................................................ 7

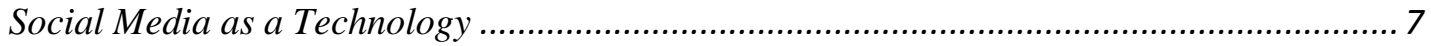

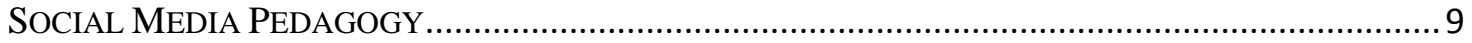

Transitional Benefits of Social Media ................................................................. 9

Educational Benefits of Social Media and Assumed Student Attitudes............................... 10

Focusing on the Student .................................................................................... 13

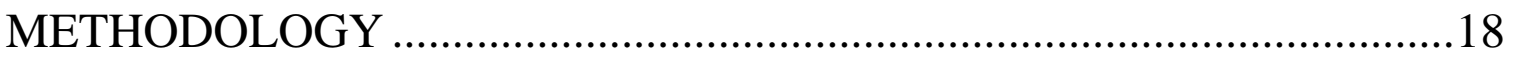

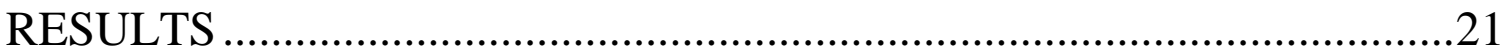

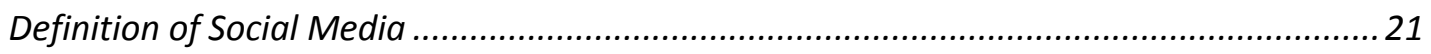

Separation of Personal and Professional Social Media Accounts..................................22

Effects on Student/Instructor Relationships ....................................................... 25

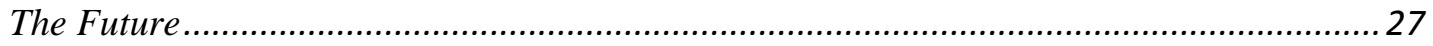

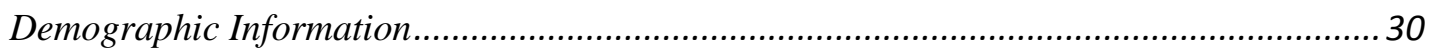

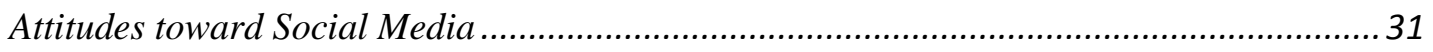

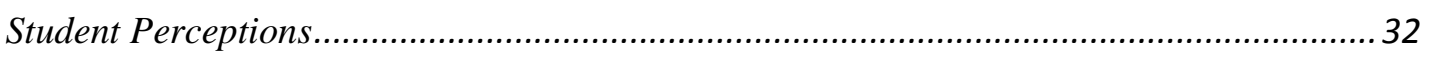

Correlating Student Attitudes and Perceptions..................................................... 35

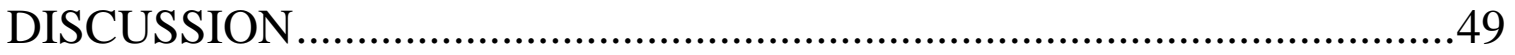

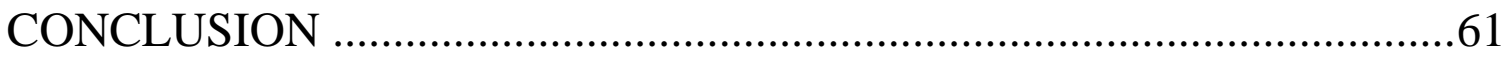

LIMITATIONS AND FUTURE RESEARCH ........................................63

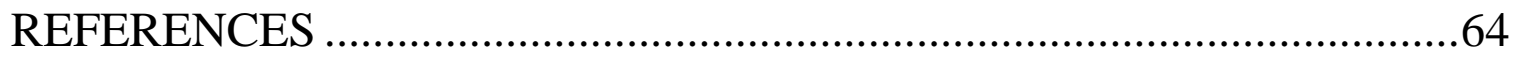

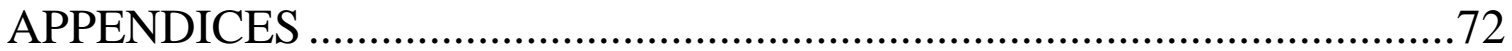

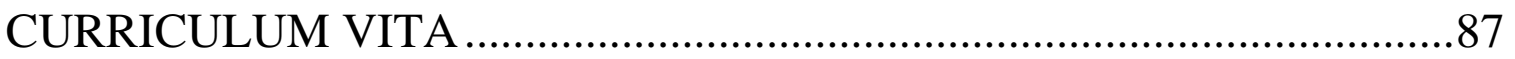




\section{INTRODUCTION}

Social media refers to platforms that are either web-based or mobile applications which allow individuals or organizations to create and engage with user generated content in digital environments (Deil-Amen, 2016). Al-Bahrani and Patel define social media as virtual communities or networks that allow participants to interact with each

other, develop communities, and share information and ideas (Al-Bahrani \& Patel, 2015). This study defines social media as a combination of both these definitions. Social media is any platform where users can generate content to share and interact with other users within a virtual, digital community. Social media websites such as Facebook, Twitter, Instagram, etc. provide platforms for individuals to connect with one and another, both professionally and socially. This technology has made the ability to connect and interact with other individuals easier compared to traditional methods of communication. Other technologies that individuals have access to, such as smartphones, tablets, and laptops provide both portability and connectivity to the internet. This makes access to social media much easier.

Modern day classrooms allow for students to bring these technologies and use them to accomplish their day-to-day goals. Students who choose to use these in the classroom occasionally find themselves using them for other activities, like accessing social media, whether the instructor is aware or not. In a study by Fried on the effects of in-class laptop use, 43 percent out of 78 students reported that they surfed the net, 68 
percent reported instant messaging, and 81 percent reported checking emails (Fried, 2008).

In a report published by the Pew Research Center on November of 2016, the rise of social media has been steadily increasing since 2005 (Greenwood, Perrin, \& Duggan, 2016). From 2005 to 2016 there has been a 64 percent increase in the use of at least one social media website by U.S. adults. There was a 79 percent rise in the use of social media by U.S. adults between the ages of 18 and 29 (Social Media Fact Sheet, 2017). The five social media platforms measured included Facebook, Twitter, Instagram, Pinterest, and LinkedIn. Facebook has consistently remained the most used social media, with 54 percent of U.S. adults using Facebook in 2005 to 68 percent using the platform in 2016. Majority of the users of social media are between the ages of $18-29$ (7 percent in 2005 and 86 percent in 2016), the age group that is traditionally associated with students, it is unsurprising that research has already been conducted on social media and its effects on education.

While most of the research conducted on the subject focuses on the effects of social media on education, this paper wants to focus specifically on the student attitudes about having to use social media in the classroom. Existing research suggests that students hold positive attitudes toward using social media as a part of their education. However, an understanding about why students have those positive attitudes is missing. The literature does not articulate if students hold the attitudes about social media out of a preference of the platform, or the proficiency the student has about using the technology, or the novelty of doing something different. Without this understanding, research about social media and education will become redundant. The goal of this study is to fill that 
gap and understand what attitudes students hold about using social media in the classroom and more importantly, why they have those attitudes. Furthermore, this paper also wants to see if there is a correlation between the attitudes students have and their perception of instructors who engage in social media with the classroom. 


\section{LITERATURE REVIEW}

This study focused on the students' attitudes of social media as used by the

professor in the classroom. There are three sections in this thesis that need to be expanded on: attitudes, education and technology, and social media pedagogy. Drawing on existing literature for these sections, this review will provide a foundation on which to build the current thesis. It will also provide a justification on the necessity of this topic by showing how this topic fills what is missing in the existing literature.

Attitudes

Understanding Attitudes

Eagly and Chaiken (1993) define attitudes as a psychological tendency which is shown in the evaluation on certain entities with some degree of favor or disfavor. Take for example, a student who has a positive attitude toward an instructor. The student will probably want to take that instructor in multiple classes. The student who has a positive attitude toward an instructor might suggest that instructor to other students. On the other hand, if a student has a negative attitude toward an instructor, the student may not want to take another class with them. The student may not be keen on coming to the instructor's class or be attentive in the class. An individual's attitude toward a person or a thing affects how their behavior is toward that person or thing. Attitudes, however, can be changed. 
Katz writes that, on a psychological level, attitudes are held on or changed based on the function they can perform for the individual (Katz, 1960). In other words, individuals hold certain attitudes to the extent they benefit from holding that attitude. This is a functional approach to attitudes which implies that attitudes can change based on the function having a certain attitude serves the individual. There are ego-defensive attitudes that are aroused by threats and can be changed by the removal of that threat. There are expressive attitudes that are aroused by individual beliefs and can be changed if the appropriate need for a new belief is shown (Katz, 1960). Having offered a foundation for attitudes, providing a definition and showing that attitudes can change, the following section highlights the theoretical premise for the current study.

The Theory of Planned Behavior

One of the more prominent theories regarding attitudes and behavior is the Theory of Planned Behavior (TPB) proposed by Icek Ajzen (Ajzen, 1985). The TPB helps to understand how the behavior of people can be changed. This theory attempts to predict deliberate behavior, because behavior has the potential to be deliberate and planned. According to the TPB there are three considerations that can affect human action. First, there are attitudes. Attitudes are the individual's opinions toward performing a given action. Second, there are the normative beliefs. Normative beliefs are "the perceived social pressure to perform or not to perform the behavior" (Ajzen, 1991, p. 188). The last consideration that can affect human action are control beliefs. Control beliefs are beliefs about the presence of factors that may facilitate or hinder the performance of the behavior. 
Looking at these beliefs separately, attitudes can produce either a favorable or unfavorable intention toward a behavioral action. Normative beliefs can affect social pressure. Control beliefs can increase perceived behavioral control. The combination of all three of these factors can lead to the creation of a behavioral action. A general rule is that the more favorable an attitude and subjective norm (societal pressure), and the greater the perceived control toward a behavior, the stronger the intention will be for the behavior to be performed.

With regards to social media, education, and student perceptions, understanding student opinions can help instructors implement social media to be more effective in their courses. This study wants to pay attention to what can causes students to hold a positive or negative perception of social media. The section below covers a review of research that has been done on social media and education. The consensus of the literature is that social media has generally positive effects in student learning when used as a tool in the classroom (Bicen, 2014; Ha \& Shin, 2014; Hunter \& Caraway, 2014; Wang et al., 2014). However, these studies conclude that students tend to have positive evaluations about using social media. They do not expand on the reasons why the students might hold those positive evaluations. The studies, also, do not provide much detail about students who might have negative evaluations of using social media in the classroom. The current study aims to fill that gap.

There are a multitude of factors that can influence a student's attitude on school, education, and instructors. The type of attitudes that students can have goes beyond just a positive and a negative attitude toward school. For example, if students are unfamiliar 
with contemporary technology, they may have anti-technology attitudes in classrooms and find the implementation of technology in the classroom an obstacle to their learning.

Student attitudes are also influenced by the use of technology in classrooms. Students who use technology are allowed the opportunity to control their own learning. Technology provides the opportunity for students to learn at their own pace or even expand on the opportunities already offered to them. It allows for students to constantly engage in education, rather than assume education happens only in a classroom (United States Department of Education National Education Technology Plan, 2010). Given this opportunity, students have shown to hold positive attitudes toward encouraging technology implementation in classrooms as a learning tool. This has resulted in an increase in higher-order thinking, writing, and problem solving (Ross, Morrison, and Lowther, 2010).

Education and Technology

Research on education and technology is not a new phenomenon. In fact, due to the existing research that shows the effectiveness of technology in classrooms, technology has become a commonplace in education. For instance, a study conducted by Davies, Lavin, and Korte (n.d.) showed that students perceived the use of technology (such as PowerPoint) positively, a conclusion which was reinforced by Schroeder et al. (2007) showing that there were positive effects on success (shown by test scores) when technology was implemented.

Social Media as a Technology

Software technologies such as Microsoft Office have become common within the educational realm and has continued to evolve. In fact, some institutions have come to 
use their own versions of social media calling them "Learning Management Systems" (LMS) such as Blackboard or Moodle. However, this study focuses on social media that were created outside of educational purposes to see if they provide any benefits to education.

These social media websites, such as LinkedIn, Facebook, Twitter, etc. are still in their infancy. LinkedIn was founded in 2003 (A Brief History of LinkedIn, n.d.) for professionals seeking to network with other professionals. Mark Zuckerberg, the founder of Facebook launched the website as a Harvard student in 2004 (Carlson, 2010). Jack Dorsey founded Twitter two years later in 2006 (Twitter turns six, 2012). While relatively young, these platforms have amassed a large user base. In the report by the Pew Research Center, Facebook maintains the highest user base at 68 percent of U.S adults using it. LinkedIn has a user base of 25 percent of U.S. adults using the platform, and Twitter maintains 21 percent of U.S. adults using the platform (Social Media Fact Sheet, 2017). These websites provide a way to be connected constantly with the world and with other people. While young, these websites, have already found their way into classrooms as evidenced by the existing research on the subject. The following section will cover what the current literature conveys about social media and education, specifically highlighting their conclusions and what is missing, providing the justification for this study.

Nevertheless, technology does not contribute to learning on its own accord. How the technology is being implemented and the degree of success in implementing the technology contributes to or detracts from learning (Tang \& Austin, 2009). Student attitudes were affected when they perceived that their instructors are applying the 
technology correctly in the classroom. From the teacher's point of view, they explained that their motivation to the technology is based on their perception of the benefits of the positive outcomes for their students (Ward \& Parr, 2010).

\section{Social Media Pedagogy}

This section aims to accomplish two objectives. First, it will examine what the current research shows about the use of social media in education and second, it will highlight a potential gap in the conclusions of the literature. The connection between social media and education is an important one to make because of the benefits social media brings to the educational process both for the student and the educator.

\section{Transitional Benefits of Social Media}

The following studies show social media as beneficial for students as they transition into the realm of higher education. In a study conducted by Hrastinski \& Dennen, they conclude that social media can provide support to learning, collaboration and community in higher educational contexts (2012). Dabbagh and Kitsantas suggest using social media to create Personal Learning Environments (PLE) as a pedagogical approach to integrating formal and informal learning (2012). These PLEs can serve students by supporting self-regulated learning at three levels: personal information management, social interaction and collaboration, and information aggregation and management.

In their paper, “'Actually, I wanted to learn': Study-related knowledge exchange on social network sites" Wodzicki, Schwämmlein and Moskaliuk (2012) examined studyrelated exchange using a German variation of Facebook, StudiVZ. They found that about one-fifth of the participants exchanged study-related knowledge through StudiVZ. Most 
of the users were first year students seeking social interaction and integration when transitioning into a college environment. DeAndrea et. al (2012) pushed further to see how social media can help students transition into college. In their paper, "Serious social media: On the use of social media for improving students' adjustment to college" they focused on a student-centered social media website designed to enhance student perceptions of social support before arriving on campus. The use of the site increased student perceptions that they would have a diverse network of social support during their initial semester at college.

These studies examine how social media can affect the transition into a higher education environment but it forgoes student opinions, which can be vital in the understanding why social media implementation is effective. Educational Benefits of Social Media and Assumed Student Attitudes

The following section show the benefits of using social media as a tool in the classroom. The conclusions show that using social media can provide pedagogical benefits which can enhance education. On a universal level, the studies conducted by Laru, Näykki and Järvelä (2012), Novak, Razzouk and Johnson (2012), Ha and Shin (2014), and Al-Bahrani, Patel and Sheridan (2015) look at some of the educational benefits of using social media.

Laru et al. (2012) explored how designed learning activities by use of social media and face-to-face activities in small groups contributed to students' learning outcomes. The study revealed that using social media tools together to perform multiple tasks was likely to increase individual knowledge acquisition. 
The findings found in Novak, Razzouk and Johnson's (2012) paper “The educational use of social annotation tools in higher education: A literature review," showed how social annotation tools have the potential to support learning in a collaborative environment and their impact on learning outcomes. Their finding suggests these tools do have pedagogical benefits, but do come with a certain learning curve. The authors recommended providing sufficient instructional support when these tools are being used.

A study conducted by Ha and Shin (2014), surveyed 324 undergraduate students in a journalism program to evaluate the function of Social Networking Sites (SNSs) as a learning tool. The results showed that while there was skepticism among the students about the use of SNSs as a learning tool, there was still a positive evaluation of the use of SNSs in a standard college class.

In a study conducted by Al-Bahrani et al. students were asked their perspectives on the use of social media in the classroom. The results of the survey conducted of 446 students indicated that students are concerned with privacy but are willing to connect with faculty as long as it is a one-way connection. The study also showed that students are willing to participate if the use of social media is a voluntary part of the class (AlBahrani et al, 2015). One of the concerns that students have in engaging with social media in the classroom is the issue of privacy. While not a major concern, a suggestion to alleviate the concern was made by the "one-way" participation where students have access to faculty or the class account, but the faculty has no access to the students' social media accounts (p. 43). The other observation made through this study is that majority of students (80.54 percent) had positive response to social media use being voluntary (p. 
44). This is an interesting observation and Al-Bahrani et al. did not take it a step further to try and understand why students prefer the social media be voluntary. The current study seeks to find out why students feel this way.

The studies highlighted below reiterate the educational benefits of social media as a tool, but focus on specific social media websites.

A study conducted by Hunter and Caraway of students attending an urban high school using Twitter found students were engaged with the content of the class even after school hours and beyond school walls (Hunter \& Caraway, 2014). Another study conducted by Bicen found that students who used Twitter along with other mobile applications had a positive effect on student opinions and caused an increase in studentteacher communication as well as global student-student communication (Bicen, 2014).

Wang, Woo, Quek, Yang, and Liu (2014), conducted a study to measure Facebook as a Learning Management System (LMS). Due to sometimes having to deal with constraints (such as cost) using LMSs such as Blackboard, Wang et al., studied whether Facebook could be substituted for current LMS in their course. The findings of the study show that Facebook has the potential for being an LMS though it does have certain constraints like not being able to support certain formats such as PowerPoint/PDF or a threaded structure for discussion.

These studies highlight the positive benefits of Twitter and potential benefits of Facebook, when used in the classroom. Hunter and Caraway show the effectiveness of Twitter in terms of its potential to expand education beyond the physical and temporal confinements of the classroom. Similarly, the study by Bicen show the benefits of Twitter in the increase of communication between the instructor and student. However, while 
both these studies are looking at Twitter as a potential tool to enhance education, it does not explain if the student's opinions on using Twitter influence the findings. There appears to be an assumption that all the students in these studies had a social media profile and preferred the use of Twitter in the classroom. Wang et al. wanted to see if Facebook could be a potential replacement for LMSs (such as Blackboard) and concludes that there are certain benefits to using it as a LMS.

A pattern emerging in the literature is the focus on social media as a beneficial tool within education. While understanding the effectiveness of social media as a tool is vital to knowing if it needs to be implemented in the classroom, it is also important to understand what student attitudes are about using these tools. Focusing on student attitudes about social media can provide a stronger understanding on how social media can be beneficial in education.

Focusing on the Student

One study focusing on student perceptions was conducted by Merle and Freberg (2016). The purpose their study was to explore whether public relations professors' presence on social media and the inclusion of a social media based assignment can influence the students' perception of a course. This study is similar to the current study since both are looking at student perception with regards to social media. Merle and Freberg found that the presence of a social media assignment positively influences students' intent to register for the course. However, this study looks specifically at PR classes and PR professors. The current study aims to understand student attitudes regardless of the discipline the student is a part of. The current study is asking a similar question to Merle and Freberg, about what are the perceptions that students hold about 
their professors' the use of social media in the classroom. But where Merle and Freberg differs from this study and is similar to others is that it's looking at student perceptions of a class that already has social media incorporated in it.

The existing literature primarily focuses on social media as a tool. Since the conclusions of the literature show that social media is a beneficial tool to education, the assumption seems to be that students have positive attitudes toward using it. This assumption needs to be clarified, which leads to the first research question posited in this paper. Without an understanding of why students feel the way they do about using social media, more research on the subject might become redundant.

R.Q. \#1: What are college student attitudes towards using social media professionally in classes?

This purpose of this study is to understand why students hold the attitudes that they do and further see if those attitudes students hold about social media influence their views about professors who engage with the students via social media. Even with a study like Bicen's which looked at student opinions of using Twitter along with other mobile applications, the students' positive opinions were based on the convenience that Twitter provided the student for the given assignment (i.e. it was measured after incorporating Twitter into the study). These studies assume many students use social media, or are familiar with social media, or they prefer social media incorporated into their classroom, or they want to combine their personal identity with their professional identity. Due to these assumptions, they may not have considered the students who are not as engaged with social media or non-traditional students who have not grown up with social media technologies which many modern students have been raised along with. These studies 
also assume that all students have access to social media via a laptop or smartphone devices.

With the first research question, the study can provide specific details about what attitudes students hold toward the use of social media in the classroom, which will help bolster the existing research by providing a deeper understanding of the student evaluations. However, the research question also provides a voice to those students who may not have positive evaluations toward using social media in the classroom. These students are given the opportunity to share why they hold those evaluations, and instructors can use that feedback to help navigate a classroom where they intend to use social media. Regardless of where the responses lean toward, it can provide for a more accommodating set of actions. For example, if student have positive attitudes toward use of social media even if they do not have access to them or are unfamiliar with social media, educators and educational administrations could consider providing these students with a way to access these technologies. On the other hand, if students have negative attitudes toward instructors using social media in the classroom, actions need to be taken to understand why that is.

However, simply understanding what and why students hold the attitudes they do is not enough. It is vital to understand if those attitudes influence how they perceive their instructors because it could impact their relationship. If the perception of instructors using social media is positive and could lead to better class performance, instructors might need to be encouraged to use social media in the classroom. If not, then how should instructors assist students to transition into a more social media oriented workplace? This leads to the second research question: 
R.Q. \#2: Do student attitudes towards social media affect their perception of a professor using social media for class?

This is an important question to answer because it touches on a vital part of the student-teacher dynamic, the interaction between them. In an article published by Maria Orlando called "Nine characteristics of a great teacher," the first three are as follows: (1) A great teacher respects students, (2) a great teacher creates a sense of community and belonging in the classroom, and (3) a great teacher is warm, accessible, enthusiastic, and caring (Orlando, 2013). These characteristics are important since it speaks to what makes a good teacher and what students seek for in their instructors in everything the instructor does. These characteristics are also centered on taking care of the student, and this is where social media perception could affect student attitudes. The proposition that this study is going with is students who perceive that teachers who encourage students to use social media for the benefit of the student are students who have positive attitudes toward social media in classroom. Students who perceive that instructors who encourage use of social media for other reasons, such as easing the job for the instructor will have negative attitudes towards social media use in classrooms. For example, if a student perceives that the instructor is encouraging them to use Facebook to build their personal brand to sell themselves better to employers, the instructor will be met with a more positive attitude than a student who perceives an instructor encouraging using social media for noneducational (i.e. contacting students, social connections) purposes.

It is important to understand what student attitudes are toward using social media and why they have those attitudes because it can affect their performances in classrooms. It also is important to know these attitudes because it can assist instructors to create a 
classroom setting that is inclusive to students with different attitudes towards social media. 


\section{METHODOLOGY}

This study was conducted through a mixed method approach. On the qualitative front, focus groups were conducted to gain a rich understanding of students' attitudes on social media use in classroom. Conducting a focus group provides students with an opportunity to explain in greater depth the details which could not be gathered quantitatively. While majority views of quantitative approaches are valid, there are criticisms (Fife, 2007). Kolitch and Dean (1999) criticized the traditional means of gathering student feedback as failing to capture critical elements of student response. Therefore, focus groups were implemented in this study to recognize these critical elements which can potentially provide a more in-depth understanding to why students might hold the attitudes that they do.

On the quantitative side, a survey was created based on the responses from the focus groups. Studies such as by Al-Bahrani et al. "Engaging students using social media: The students' perspective” (2015) and Rosen, Whaling, Carrier, Cheever, \& Rokkum (2013) "The Media and Technology Usage and Attitudes Scale: An empirical investigation" have implemented surveys to gain a greater evaluation of their results.

In this study, the qualitative approach involved focus groups of 3 to 7 students, which were not representative of the larger college campus. The use of the mixed method approach sought to resolve the areas in where both quantitative and qualitative approaches were lacking. 
Prior to conducting the focus groups and distributing the survey, a pilot test was conducted for both. The pilot focus group conducted had 6 participants. The goal for the pilot test was to ensure the questions that would be delivered to the official focus group were appropriate to the research question posed. Once the pilot focus group was complete, the questions that were provided were confirmed and used during the official focus groups. Once the data from the focus groups were gathered, the survey was created and was put through a pilot test. The pilot survey was given to a class of 60 students. The pilot survey was delivered to gain insight from the students about improvements (such as length of the survey or if the questions needed to be rephrased) which could be implemented to the final survey.

Three focus groups were conducted, each with seven, three, and five students respectively totaling 15 participants. Participants in this study were from multiple degree programs at a major university in the Midwest. The participants were full time undergraduate students enrolled in communication and general education courses. These focus groups were conducted by the primary researcher of the study. Each focus group took between 50 minutes to one hour. The students were asked to sign a consent form before beginning the discussion. Students were offered refreshments for their participation. The questions asked in the focus groups are attached in Appendix A. The focus groups were audio recorded and the recordings were saved on the private, password protected computer belonging to the primary researcher. These questions are qualitative measurements that can help create a survey that will be conducted to a larger sample size.

The researcher transcribed the focus groups looking for emerging themes via grounded theory. After the transcriptions of the focus groups were completed, the 
researcher read through all three transcripts looking for concepts, words, and phrases that repeated in all three transcripts. Only the themes present in all three focus groups led to the major themes. These themes were used to create the survey.

The survey was delivered to 1000 students from communication and general education classes provided in the university. The response rate was 35.8 percent. However, 6.7 percent of the responses was removed due to the surveys not being completed or certain questions being left unanswered. The data used in this study was taken from the remaining surveys $(n=334)$.

General education courses tend to have students from multiple disciplines which will provide for diversity in student education. More diversity in student educational disciplines and large sample size provides for a more accurate representation of a college campus. These courses also provide a large quantity of students for the sample sizes. The instructors of the class sent the link for the survey via email and/or published the link as an announcement on Blackboard. Some instructors chose to provide extra credit for completing the survey, while providing other extra credit opportunities for those who did not want to take the survey. Other instructors did not offer any compensation for the students leaving the option to take the survey a voluntary decision of the student. The primary researcher was given a few minutes to explain the study to the class as the survey is introduced to the class. Once the survey was distributed, students had a two-week period to finish it. The survey can be found in Appendix B.

Once the survey data was gathered, a series of Pearson Correlation calculations were conducted to examine any relationships between student attitudes and their perception of instructors using social media. 


\section{RESULTS}

The focus groups achieved two goals. First, they provided an answer to the first research question. Second, the data gathered from the discussions allowed the researcher to create a survey to measure if the attitudes shared in the focus groups were replicated with a larger sample size.

Definition of Social Media

To ensure that all students were on the same page, the definition of social media needed to be established. Based on the responses, the definition agreed upon was the definition laid out by Deil-Amen (2016) and Al-Bahrani \& Patel (2015): any platform where users can generate content to share and interact with other users within a virtual, digital community

The focus groups showed that there were a lot of differing opinions on the use of social media in classrooms. These opinions were based on various reasons ranging from proficiency of using social media to social media being viewed as a distraction. The responses have been divided into three themes: separation of personal and professional social media accounts, effects on student and instructor relationships, and the future. There were a few comments that were made that are worth noting but did not fall into any of the three themes mentioned. 
Separation of Personal and Professional Social Media Accounts

It is important to note that this topic had students respond in a positive, negative, and neutral manner. One of the reasons that students provided for not wanting to engage in social media in the classroom was because it infringed on their personal space.

"I was just going to say that I wouldn't be too thrilled about a professor asking us to use social media, just because that's my personal page, and when the professor asks us to start posting Tweets maybe about certain things, or posting certain items on Facebook, or use this word ... I don't even know how a professor would ask us to use social media, but when they ask us to start posting things to get ready for their class on our social media pages, that just, kind of, I feel like, takes that away from being my page, and it's now mine and my teacher's page.” (Participant 5, Focus Group I)

Some of the participants viewed their social media profiles as solely their own and wanted full ownership of those profiles. They wanted anything that they put on their profiles to be a choice that they make. They did not find the idea that their posts or tweets be influenced by an instructor or by an assignment appealing. Those students who did not want to engage with social media in the class justified that by saying that it was no longer their personal page if the posts on it were based of their instructors' requirements.

Another reason that students opposed the idea of using social media in the class was because it changes who the audience of their profiles might be. One of the focus groups (focus group III) had students who had to create blogs for one of their assignments. This was the students' response to that assignment:

"I kind of hate that I have to have a blog for one of my classes because, like, I choose who I share my stuff with on social media but now like my whole class can read, 
like, my blog. And I just find that, like, weird, because I didn't like choose for them to like have access. " (Participant 1, Focus Group III).

This sentiment was echoed by another participant in the same group, but with the addition of being critiqued. The student did not like to use a blog because it was being viewed by the students as well as the instructor and the student did not like the idea of being critiqued by the classmates as well as the instructor.

"It is kind of weird to know that other people can read your stuff and critique it and go off of it and judge it, when honestly I only did it for the teacher. I didn't ask for your opinion. And then, I also had this happen in a Spanish class where we had to post on a Facebook page, and it's just weird having over a hundred other people read your stuff in Spanish when you can barely speak it." (Participant 5, Focus Group III).

However, these attitudes were not unanimous. When asked for other participants' opinions on this response, one student responded with indifference. This student said that they did not care that others might be able to see their blogs, because they "put it all out there to an extent. To an extent" (Participant 2, Focus Group III). According to participant 2, they choose how much to put on the blogs and because they get to choose what to share, they share as much as they feel comfortable with. The student participant also claimed that they are fine with sharing the blogs because it could potentially benefit someone who views it.

Rather than refusing to use social media, students have found a way around having to use their personal profiles for engaging with their classes. Students from all three focus groups said that they create another account (anonymous or not) for the class. They create these accounts for the sole purpose of the classroom. One student, though, 
differentiated "professional" between classroom and the workplace. This student claimed that while they would not have an issue with the supervisor at the workplace being friends online, they do not want to give that same access to the professor. When asked about their thoughts on the merging of their personal and professional lives on social media, the student said:

"My job can see what I do just because I have to write on the Facebook page for my job. And my boss, I'm close to my boss, we're friends on Facebook. So that's not necessarily my problem. Its just I don't necessarily want my professor just getting on my Instagram and looking at my pictures from music festivals or looking at my Twitter. And, its my social media” (Participant 1, Focus Group III).

The students mentioned that though they might create a different account for engaging with instructors on social media in the context of the classroom, they would be willing to connect with the instructors once they had graduated from that class.

Participant 5 of Focus Group III said that they would have no issues with connecting with the professors after completing the class because they viewed that connection as a potential to get a referral in the future. When the students were asked if they were more likely to interact with a professor on social media after they had completed the course three out of the five participants said "yes."

One of the reasons the students claimed that they'd like using a website such as Facebook even if they did not like the social networking website is because it has made contacting classmates easier. Though the students wanted to separate their personal and their professional profiles, one student believed that Twitter succeeded where Blackboard (where there are email lists of their classmates) fails. 
“There's plenty of people that I know their first name, I don't know their last name, but I know what they look like, and I can like ... there are so many people I've literally just DM-ed on Twitter and been like, "Hey, do you know when this homework is due, or can you help me with this, or that" (Participant 7, Focus Group 1).

She makes the point that contacting students is easier with social media since all that is required to look for someone on a social network such as Facebook or Twitter is their first name and a photo. The student implies this ease because websites such as Blackboard provide email lists where you could contact a classmate, but it does not provide photos. This is problematic since there could potentially by multiple people with the same first name.

\section{Effects on Student/Instructor Relationships}

The questions about how the relationship between instructor and student relationships might be affected was posed to all three focus groups and the responses in all three groups were varied. Some participants did not see much of an effect on the relationship between the two if they engaged online, while others thought it affected how they would behave online.

"If a teacher wants to use more social media, I feel like I would have to have another Twitter. To keep it more professional and stuff like that. Because I don't think you're able to be fully yourself if you think somebody's watching you. Somebody important.” (Participant 1, Focus Group 2).

Some students believed that instructors should not care what students posted on their online profiles. The responses reflected the belief that engagement online was fine as long as it remained professional. One participant put it like this, "I think for me I'm 
here to learn the content of the classroom from the professor. I'm not here for you to learn about what I do on my personal time" (Participant 3, Focus Group III). This participant also did not like the idea that an instructor might be able to hold them accountable for not submitting an assignment on time because the professor could see what they were doing over the weekend. The student likened that interaction to an interaction one might have with a parent, "I just think back to how your parents are. 'Oh, well, you didn't get your homework done? You weren't able to turn in this assignment? Well, I've seen you out with your friends all weekend because you're posting about it" (Participant 3, Focus Group III).

A different reaction to this question was the instructor being indifferent to the relationship since the instructor will be interacting with a large number of students and the instructor would not have time to pay attention to any one student's online profile. Participant 4 from Focus Group III puts it this way, "I would say it doesn't hold much value for the instructor because of sheer number of students that they have that the odds of them randomly selecting your profile and going through it, I wouldn't be very concerned of it." When pressed some more about the student and the instructor actively interacting online and thus giving easier access to their profile the student said, "I would say it has no effect on the relationship." In response to this, a student disagreed with them and said that they have seen movies where student and teacher relationships could be a bad thing (Participant 2, Focus Group III). The student brought up that it could provide a platform for stalking and found it "weird" when an instructor "likes" their post.

This students' disagreement was also raised in Focus Group I. Participant 5 made the claim that there would be a rise in students and teachers "getting together" and " $a$ rise 
in problems of students complaining to the directors of the program that they're being creeped out by what the teacher is doing." In response to this, Participant 7 claimed that while social media might provide another channel for these relationships to occur, they were going to happen anyway. The student points out that this was why syllabi have sexual harassment sections. In addition, Participant 1 suggested that instead of not using social media at all "we need to find ways to make sure that doesn't happen. So like specifically creating class accounts, and not having personal accounts used, for example."

One student mentioned the interaction online between instructors and students can make the relationship informal. When asked if that was a positive or a negative, the student took the middle ground and said:

"I think it can go both ways, for the fact that it's a good thing that you do get to look into their lives, and you do get to see more of a real side to them, but at the same time, it does make you more vulnerable to the fact that if you had homework, or if you did not give your fullest effort, then they can be like, "I know why, and it's because you went out all weekend." I think it works both ways" (Participant 6, Focus Group I).

\section{The Future}

One of the recurring themes that most of the student participants acknowledged was social media being used in the mainstream today.

"We are the generation of social media" (Participant 2, Focus Group I)

While the participants did have opposing attitudes to the use of social media in the classroom and by the instructors, they seem to agree that it is a tool that is currently being used by companies and will continue to be used. Some participants viewed social media 
as a valuable tool in terms of marketing and strategic communication. One student brought his personal experience with using social media as a promotional tool to emphasize this point, "I'm actually in a band, and we use social media ridiculously to actually promote our stuff. I did know that actually having a start-up company also, and we do the same thing with that. It helps sales, it helps everything we possibly think of. In that aspect, I think social media is a wonderful thing" (Participant 4, Focus Group I).

When students were asked why they thought some instructors used social media in the classroom, one student responded saying, "It's basically the new way of technology. Trying to keep up with the future" (Participant 2, Focus Group III). In addition, the student participant also mentioned that instructors might engage with social media because it is easier for instructors to use social media. Another student points out that since this is the generation of social media, "if you're going to apply for a job, they're going to look up your social media accounts" (Participant 7, Focus Group I). This point of view is echoed by another student where they said, "I feel like jobs, if they want to see something, they're going to see it" (Participant 1, Focus Group 2). Even the students who were opposed to the idea of using social media in class, whether they used social media personally or not, claimed that if there is an advantage for students to use social media as a part of their education, the opportunity should be offered to them. Participant 4 in Focus Group III puts it this way, "I would say that as long as it is advantageous to every student then there's no dilemma in using social media in a classroom."

When asked if allowing the use of social media in the classroom was a positive or a negative, even the students who admitted to it being a useful tool saw social media as a distraction. The point that social media can be used to broaden educational lines past the 
classroom location and time and how social media allowed for an ease of sharing information was made, the argument against that was students don't have the attention span to focus on that information alone. In other words, when students are asked to visit a link to an article or engage in a discussion about a topic on Facebook, they could easily be distracted by the other features provided by Facebook.

"I can see Participant 1 and Participant 7's side of the argument, saying that the added communication, or the added resource of that communication will further help the ideas to spread and better understand the information being presented, but at the same time, playing that middle ground, I still think that social media, when actively presented to students is far more a distraction... When we come with Blackboard, you know, Blackboard doesn't play video games. Blackboard is pretty much straight cut, has all the things that you need, whereas Facebook; if you have a Facebook group, 'Yeah, sure, I'm paying attention. Dude, you just shot down my tank.' Going through the reality of it, we're all slightly ADHD” (Participant 2, Focus Group I).

Students were asked if their attitudes on using social media might be affected if the instructor's intention for using it was to keep students updated on the constant change of social media and the response was dependent on circumstances. One student believed that social media belonged in only marketing courses.

"The only way I can think of using social media in the business world is from a marketing standpoint. So like a marketing class would be great to learn how to use social media, and I've had a marketing class where we went through different social media, and that was really helpful to see how businesses use that, but in a public speaking COMM class, there's no need to use social media" (Participant 5, Focus Group I). 
Another student felt that the intention would be fruitless since they have grown up with social media and they have a level of confidence (and potentially more skill) with using social media than the instructors. However, the participant added that there is room to be taught how to be professional online.

"I feel like we already know about social networks, and I think more than they do. I think the only thing they can teach us is how to be professional" (Participant 1, Focus Group II).

The data gathered from the focus groups provided an answer to the first research question. It showed that positive evaluations of using social media are not unanimous. There are students who hold negative evaluations about using social media in the classroom and there are students who are indifferent toward it. Having gathered the information from the focus groups, a survey was created asking specific questions related to each of the themes that rose from the focus groups.

\section{Demographic Information}

Out of the 334 survey participants, 107 were male and 227 were female. The academic years of the students were divided as follows: 126 Freshman, 82 Sophomores, 75 Juniors, and 48 Seniors. Three participants did not report their academic years. The most used social media application among the participants of the survey was Snapchat, with 24 percent of the respondents using the application. At 22.2 percent, Facebook was the second highest used social media application and Pinterest was the third highest used application with 16.8 percent of respondents claiming to use it. The two lowest used social media applications were Tumblr and LinkedIn, with only .6 percent of the respondent claiming to use each of them. The demographic differences between student 
genders and student academic standing and their attitudes are highlighted in Tables 5 16.

The survey sought to find out if there was a correlation between student attitudes toward social media and how they perceived instructors who used social media in the classroom. Questions about student attitudes toward social media were based on 3 categories: voluntariness, proficiency of use, and the separation of personal and professional profiles. The questions about student perceptions were based on four categories: how the student/instructor relationship was affected, the perceived influence instructors might have on their social media posts, the harmfulness of using social media, and the benefits of using social media.

\section{Attitudes toward Social Media}

The means of each category under attitudes and perspectives were calculated via a descriptive analysis on SPSS. Under attitudes, when asked if the student would voluntarily participate with social media the average for voluntariness (voluntariness_ATT) was $M=1.27(\mathrm{n}=334, S D=.44)$. The remaining three categories used to measure attitude, were measured on a 5-point Likert scale ranging from "Strongly Agree" (1) to "Strongly Disagree" (5). There were three questions on the survey measuring proficiency of use. The first question asked students if they agreed or disagreed with the statement, "I do not need to be taught how to use social media" (proficiency_ATT). The mean score for this statement was $M=1.94,(\mathrm{n}=334, S D=$ 1.05) leaning closer to "strongly agree." Following that, students were asked to respond to this statement, "I am more proficient in using social media than my instructors" (proficiency_2_ATT) The mean response to this statement was $M=2.16(\mathrm{n}=334, S D=$ 
.92), still remaining on the "agree" side of the scale, closer to the middle. The last statement students were asked regarding proficiency was if students felt they had more to learn about using social media (proficiency_3_ATT). The average score for this statement is $M=2.40(\mathrm{n}=334, S D=1.10)$, staying almost neutral, but still agreeing that they had more to learn.

The next category measuring attitude was the separation of personal and professional profiles. Two survey questions items were offered to the students under this category. The first statement declared, "I like to separate my personal social media account from my professional social media account" (separation_ATT). The mean score to this statement was $M=2.21(\mathrm{n}=334, S D=1.12)$ showing that students prefer to use social media in classroom if it did not step into their personal profile. The second statement about separation stated, "I would use social media in class if I had a separate account" (separation_2_ATT). The mean score for this statement was $\mathrm{M}=2.19(\mathrm{n}=334$, $S D=1.06$ ), showing that students were positively inclined to use social media if they could have a separate account for use in the classroom.

\section{Student Perceptions}

Student perspective of instructors using social media was measured based on four categories: how the relationship was affected, the benefits and harmfulness of using social media and the level of perceived influence their instructors could have on their social media posts. On a 5 point Likert scale, students were asked if they agreed or disagreed with the statements involving the 4 perspectives mentioned above.

With regards to perceived influence, students were asked if their social media posts were affected if they knew their professors could view them (influence_PER). The 
average response was $M=2.66(\mathrm{n}=334, S D=1.22)$ showing that students were primarily neutral about perceived influence the instructor had on their posts, but leaning toward disagreeing with the statement. The second item offered to the students stated, "I can't be myself if my social media can be seen by an authority figure" (influence_2_PER) The mean response to this statement was $M=3.27(\mathrm{n}=334, S D=$ 1.21) reinforcing the response from the first statement about perceived influence. Students did not agree with the statement that their posts are influenced by an authority figure.

The second category involving student perceptions was based on the relationship between student and instructor. Students were offered two statements to respond to with this category. The first item stated, "Your relationship with your instructor will be affected if you interact via social media." The mean response to this statement was $M=$ $2.88(\mathrm{n}=334, S D=1.06)$ showing that students disagreed that their relationship were affected if they interacted with their instructors via social media. When students were asked a more specific statement about how their relationship with the instructor could be affected, "Online interactions between student and instructor makes the relationship more informal," the mean response showed $M=2.52(\mathrm{n}=334, S D=.97)$. This tells that students mainly remained neutral about their agreeableness that student and instructor could become more informal if they engaged with each other online.

The third category assessing student perspectives were based on their perceived benefits of using social media in the classroom. This category was measured by offering students 3 statements measuring the perceived benefits. The first statements said, "I do not think social media offers my any benefit professionally" (beneficial_PER). The mean 
response to this statement was $M=3.62(\mathrm{n}=334, S D=1.07)$ showing that students disagreed with the notion that social media does not offer professional benefit. The next two statements provided to students to measure the benefits were provided on a 5 point Likert scale, ranging from Harmful (1) to Beneficial (5). The second statement posited was, "Overall, I think that using social media for class is..." (beneficial_2_PER). The average response was, $M=3.30(\mathrm{n}=334, S D=.95)$ showing that majority students perceive using social media in class as beneficial. Interestingly, the third statement posited to the students, "Overall, I think that not having to use social media for class is..." (beneficial_3_PER) was asked to see if the responses might echo the response of the previous statement. Instead, the mean score shows, $M=3.23(\mathrm{n}=334, S D=.82)$ telling that majority of students also perceive not using social media in the classroom as beneficial.

The final category measuring student perceptions involved perceived harmfulness. Students were offered two statements about perceived harmfulness. The first statement posited, "Social media is a tool, but is also a distraction" (harmful_PER). The average response to this statement was $M=1.72(\mathrm{n}=334, S D=.76)$ showing that majority of students strongly agreed that social media, while a tool, was a distraction. When asked if "social media negatively affected student's attention span," the average response confirmed the response from the previous statement, $M=1.96(\mathrm{n}=334, S D=$ .78). This shows the average response to social media negatively affecting student's attention span leaned strongly toward agreement. 


\section{Correlating Student Attitudes and Perceptions}

A series of Pearson Correlations were conducted to see if there was a linear relationship between the attitudes held by the student and their perceptions of instructors using social media. The results can be seen below under Table 4 . There were no statistical significant correlations found between students who agreed with the statement, "I do not need to be taught how to use social media" and their perception of instructors using social media in the classroom. There was also no statistical significance between students preferring to separate their personal and professional accounts and their perceptions of using social media in the classroom.

However, a negative correlation was found between students willing to participate in social media voluntarily and online interactions making the relationship between student and instructor more informal $(\mathrm{r}=-.137, \mathrm{p}=.012)$. There was also a negative correlation between voluntariness and both statements of influence. As voluntariness of participation increased, social media posts are less affected knowing the professor could view them $(\mathrm{r}=-.135, \mathrm{p}=.013)$.

As voluntariness increased, the less likely a student feels like they cannot be themselves on social media $(r=-.131, \mathrm{p}=.017)$. Finally, there is a negative correlation between voluntariness and perceiving social media as a distraction. The results show that the more social media participation is voluntary, the less likely it is a distraction $(\mathrm{r}=$ $.113, \mathrm{p}=.038)$.

A positive correlation show that student posts are affected more if they view themselves as more proficient than their instructors in using social media $(\mathrm{r}=.121, \mathrm{p}=$ .028). However, there was a negative correlation found between students who viewed 
themselves as more proficient than their instructors and students perceiving not using social media as beneficial $(\mathrm{r}=-.108, \mathrm{p}=.048)$. In other words, students who viewed themselves as more proficient at using social media than their instructors, perceived not using social media in the classroom as less beneficial. 
Table 1

College Department and Academic Standing Demographics

\begin{tabular}{|c|c|c|c|c|c|c|}
\hline & & \multicolumn{4}{|c|}{ Academic Standing } & \multirow[t]{2}{*}{ Total } \\
\hline & & Freshmen & Sophomores & Juniors & Seniors & \\
\hline \multirow[t]{7}{*}{ Department } & College of Law & 1 & 1 & 0 & 0 & 2 \\
\hline & $\begin{array}{l}\text { College of Arts and } \\
\text { Science }\end{array}$ & 53 & 49 & 52 & 36 & 190 \\
\hline & College of Business & 21 & 10 & 8 & 3 & 42 \\
\hline & College of Education & 23 & 11 & 13 & 8 & 55 \\
\hline & $\begin{array}{l}\text { College of Health } \\
\text { Professions }\end{array}$ & 16 & 7 & 1 & 0 & 24 \\
\hline & Speed School & 1 & 1 & 0 & 1 & 3 \\
\hline & $\begin{array}{l}\text { Have not declared a } \\
\text { Major }\end{array}$ & 11 & 3 & 1 & 0 & 15 \\
\hline Total & & 126 & 82 & 75 & 48 & 331 \\
\hline
\end{tabular}


Table 2

College Department and Gender Demographics

\begin{tabular}{llrrr}
\hline & & \multicolumn{2}{c}{ Gender } & \\
\cline { 3 - 4 } & & Male & Female & Total \\
\hline \multirow{2}{*}{ Department } & College of Law & 0 & 2 & 2 \\
& College of Arts and Science & 52 & 139 & 191 \\
& College of Business & 24 & 18 & 42 \\
& College of Education & 24 & 32 & 56 \\
& College of Health Professions & 1 & 23 & 24 \\
& Speed School & 2 & 1 & 3 \\
& Hotal & 4 & 12 & 16 \\
& & 107 & 227 & 334 \\
\hline
\end{tabular}

Table 3

Academic Standing and Gender Demographics

\begin{tabular}{llrrr}
\hline & & \multicolumn{2}{c}{ Gender } & \\
\cline { 3 - 4 } & & Male & Female & Total \\
\hline Academic Standing & Freshmen & 39 & 87 & 126 \\
& Sophomores & 21 & 61 & 82 \\
& Juniors & 29 & 46 & 75 \\
& Seniors & 17 & 31 & 48 \\
Total & & 106 & 225 & 331 \\
\hline
\end{tabular}


Table 4

Most Used Social Media Websites

\begin{tabular}{llrrrr}
\hline & & & & \multicolumn{2}{c}{ Cumulative } \\
& & Frequency & Percent & Valid Percent & Percent \\
\hline Valid & Facebook & 74 & 22.2 & 22.3 & 22.3 \\
& Twitter & 40 & 12.0 & 12.0 & 34.3 \\
& Pinterest & 56 & 16.8 & 16.9 & 51.2 \\
& Snapchat & 80 & 24.0 & 24.1 & 75.3 \\
& Instagram & 51 & 15.3 & 15.4 & 90.7 \\
& Youtube & 15 & 4.5 & 4.5 & 95.2 \\
& Blogger & 6 & 1.8 & 1.8 & 97.0 \\
& Reddit & 5 & 1.5 & 1.5 & 98.5 \\
& Tumblr & 2 & .6 & .6 & 99.1 \\
& LinkedIn & 2 & .6 & .6 & 99.7 \\
& Other & 1 & .3 & .3 & 100.0 \\
Missing & Total & 332 & 99.4 & 100.0 & \\
& System & 2 & .6 & & \\
\hline
\end{tabular}

Table 5

Voluntariness and Gender

\begin{tabular}{lcr|rr}
\hline & & \multicolumn{2}{c|}{ Gender } & \\
\cline { 3 - 4 } & & Male & \multicolumn{1}{c}{ Female } & \multicolumn{1}{c}{ Total } \\
\hline Voluntariness_ATT & Yes & 74 & 171 & 245 \\
& No & 33 & 56 & 89 \\
Total & & 107 & 227 & 334 \\
\hline
\end{tabular}


Table 6

Voluntariness and Academic Standing

\begin{tabular}{llr|rr|rr}
\hline & & \multicolumn{4}{c|}{ Academic Standing } & Total \\
\cline { 3 - 7 } & & Freshmen & Sophomore & Juniors & Seniors & \\
\hline \multirow{2}{*}{ Voluntariness_ATT } & Yes & 84 & 59 & 55 & 45 & 243 \\
& No & 42 & 23 & 20 & 3 & 88 \\
Total & & 126 & 82 & 75 & 48 & 331 \\
\hline
\end{tabular}

Table 7

Separation (1) and Gender

\begin{tabular}{llr|rr}
\hline & & \multicolumn{2}{c}{ Gender } & \\
\cline { 3 - 4 } & & Male & \multicolumn{1}{c}{ Female } & \multicolumn{1}{c}{ Total } \\
\hline Separation_ATT & Strongly Agree & 28 & 82 & 110 \\
& Agree & 30 & 72 & 102 \\
& Neither & 33 & 43 & 76 \\
& Disagree & 11 & 22 & 33 \\
& Strongly Disagree & 5 & 8 & 13 \\
Total & & 107 & 227 & 334 \\
\hline
\end{tabular}

Table 8

Separation (1) and Academic Standing

\begin{tabular}{llr|rr|rr}
\hline & & \multicolumn{3}{c|}{ Academic Standing } & Total \\
\cline { 3 - 7 } & & Freshmen & Sophomore & Junior & Senior \\
\hline Separation_ATT & Strongly Agree & 41 & 30 & 29 & 8 & 108 \\
& Agree & 38 & 27 & 22 & 14 & 101 \\
& Neither & 30 & 17 & 14 & 15 & 76 \\
& Disagree & 13 & 5 & 8 & 7 & 33 \\
& Strongly Disagree & 4 & 3 & 2 & 4 & 13 \\
Total & 126 & 82 & 75 & 48 & 331 \\
\hline
\end{tabular}


Table 9

Separation (2) and Gender

\begin{tabular}{llr|rr}
\hline & & \multicolumn{2}{c}{ Gender } & \multicolumn{2}{c}{ Total } \\
\cline { 3 - 4 } Separataion_2_ATT & Strongly Agree & 23 & 75 & 98 \\
& Agree & 36 & 92 & 128 \\
& Neither & 29 & 36 & 65 \\
& Disagree & 14 & 19 & 33 \\
& Strongly Disagree & 5 & 5 & 10 \\
Total & & 107 & 227 & 334 \\
\hline
\end{tabular}

Table 10

Separation (2) and Academic Standing

\begin{tabular}{|c|c|c|c|c|c|c|}
\hline & & \multicolumn{4}{|c|}{ Academic Standing } & \multirow[t]{2}{*}{ Total } \\
\hline & & Freshmen & Sophomore & Junior & Senior & \\
\hline \multirow{6}{*}{$\begin{array}{l}\text { Separation_2_A } \\
\text { TT }\end{array}$} & Strongly & 41 & 27 & 17 & 10 & 95 \\
\hline & Agree & & & & & \\
\hline & Agree & 42 & 37 & 34 & 15 & 128 \\
\hline & Neither & 23 & 12 & 16 & 14 & 65 \\
\hline & Disagree & 16 & 5 & 5 & 7 & 33 \\
\hline & $\begin{array}{l}\text { Strongly } \\
\text { Disagree }\end{array}$ & 4 & 1 & 3 & 2 & 10 \\
\hline Total & & 126 & 82 & 75 & 48 & 331 \\
\hline
\end{tabular}

Table 11

Proficiency (1) and Gender

\begin{tabular}{llr|rr}
\hline & & \multicolumn{2}{c}{ Gender } & \\
\cline { 3 - 4 } & & Male & Female & \multicolumn{1}{c}{ Total } \\
\hline Proficiency_ATT & Strongly Agree & 44 & 100 & 144 \\
& Agree & 34 & 75 & 109 \\
& Neither & 21 & 23 & 44 \\
& Disagree & 8 & 23 & 31 \\
& Strongly Disagree & 0 & 6 & 6 \\
Total & & 107 & 227 & 334 \\
\hline
\end{tabular}


Table 12

Proficiency (1) and Academic Standing

\begin{tabular}{llr|rr|rr}
\hline & & \multicolumn{3}{c|}{ Academic Standing } & \multicolumn{2}{c}{ Total } \\
\cline { 2 - 7 } & & Freshmen & Sophomore & Junior & Senior & \\
\hline Proficiency_ATT & Strongly & 56 & 45 & 28 & 14 & 143 \\
& Agree & & & & & \\
& Agree & 45 & 19 & 23 & 21 & 108 \\
& Neither & 19 & 8 & 10 & 7 & 44 \\
& Disagree & 4 & 10 & 13 & 3 & 30 \\
& Strongly & 2 & 0 & 1 & 3 & 6 \\
& Disagree & & & & & \\
Total & 126 & 82 & 75 & 48 & 331 \\
\hline
\end{tabular}

Table 13

Proficiency (2) and Gender

\begin{tabular}{llr|rr}
\hline & & \multicolumn{2}{c|}{ Gender } & \\
\cline { 3 - 4 } & & Male & \multicolumn{1}{c}{ Female } & \multicolumn{1}{c}{ Total } \\
\hline Proficiency_2_ATT & Strongly Agree & 24 & 67 & 91 \\
& Agree & 45 & 78 & 123 \\
& Neither & 33 & 68 & 101 \\
& Disagree & 2 & 13 & 15 \\
& Strongly Disagree & 3 & 1 & 4 \\
Total & & 107 & 227 & 334 \\
\hline
\end{tabular}


Table 14

Proficiency (2) and Academic Standing

\begin{tabular}{llr|rr|rr}
\hline & & \multicolumn{3}{c|}{ Academic Standing } & Total \\
\cline { 2 - 7 } & & Freshmen & Sophomore Junior & Senior & \\
\hline Proficiency_2_ATT & Strongly & 41 & 23 & 15 & 11 & 90 \\
& Agree & & & & & \\
& Agree & 44 & 29 & 29 & 21 & 123 \\
& Neither & 38 & 21 & 26 & 15 & 100 \\
& Disagree & 3 & 7 & 4 & 0 & 14 \\
& Strongly & 0 & 2 & 1 & 1 & 4 \\
Total & Disagree & & & & & \\
& & 126 & 82 & 75 & 48 & 331 \\
\hline
\end{tabular}

Table 15

Proficiency (3) and Gender

\begin{tabular}{llr|rr}
\hline & & \multicolumn{2}{c}{ Gender } & \multicolumn{2}{c}{ Total } \\
\cline { 3 - 4 } Proficiency_3_ATT & Strongly Agree & Male & \multicolumn{1}{c}{ Female } & \multicolumn{2}{c}{ Th } \\
& Agree & 25 & 47 & 733 \\
& Neither & 25 & 96 & 133 \\
& Disagree & 13 & 35 & 67 \\
& Strongly Disagree & 7 & 7 & 14 \\
Total & & 107 & 227 & 334 \\
\hline
\end{tabular}


Table 16

Proficiency (3) and Academic Standing

\begin{tabular}{llr|rr|rr}
\hline & \multicolumn{3}{c}{ Academic Standing } & Total \\
\cline { 3 - 7 } & & Freshmen & Sophomore & Junior & \multicolumn{2}{c}{ Senior } \\
\hline Proficiency_3 & Strongly Agree & 25 & 17 & 15 & 13 & 70 \\
\multirow{2}{*}{ ATT } & Agree & 45 & 34 & 33 & 20 & 132 \\
& Neither & 25 & 12 & 18 & 12 & 67 \\
& Disagree & 22 & 16 & 7 & 3 & 48 \\
& Strongly & 9 & 3 & 2 & 0 & 14 \\
& Disagree & & & & & \\
Total & & 126 & 82 & 75 & 48 & 331 \\
\hline
\end{tabular}


Table 17

Results of Pearson Correlations between Student Attitudes and Student Perceptions

\begin{tabular}{|c|c|c|c|c|c|c|c|c|c|c|c|c|c|}
\hline & & \multicolumn{3}{|l|}{ Volun } & \multicolumn{5}{|c|}{ Separ } & \multicolumn{3}{|c|}{ Har } & \multirow{2}{*}{$\begin{array}{c}\text { Influe } \\
\text { nce }\end{array}$} \\
\hline & & tarine & Profici & Profici & Profici & Separat & ation_ & Benefi & Benefi & Benefi & mful & Influe & \\
\hline & & ss & ency & ency_2 & ency_3 & ion & 2_AT & cial_P & cial_2 & cial_3 & _PE & nce & _2_PE \\
\hline & & ATT & ATT & ATT & ATT & ATT & $\mathrm{T}$ & ER & PER & PER & $\mathrm{R}$ & PER & $\mathrm{R}$ \\
\hline \multirow{6}{*}{$\begin{array}{l}\text { Voluntari } \\
\text { ness }\end{array}$} & Pearson & 1 & -.004 & -.006 & $.108^{*}$ & - & .001 & - & - & $.162^{* *}$ & - & $-.135^{*}$ & $-.131^{*}$ \\
\hline & Correlat & & & & & $.144^{* *}$ & & $.190^{* *}$ & $.307^{* *}$ & & $.113^{*}$ & & \\
\hline & ion & & & & & & & & & & & & \\
\hline & Sig. (2- & & .937 & .908 & .048 & .008 & .980 & .000 & .000 & .003 & .038 & .013 & .017 \\
\hline & tailed) & & & & & & & & & & & & \\
\hline & $\mathrm{N}$ & 334 & 334 & 334 & 334 & 334 & 334 & 334 & 334 & 334 & 334 & 334 & 334 \\
\hline \multirow[t]{6}{*}{ proficien } & Pearson & -.004 & 1 & $.448^{* *}$ & $-.214^{* *}$ & .059 & .078 & .071 & .103 & -.100 & $.296^{*}$ & -.037 & .065 \\
\hline & Correlat & & & & & & & & & & * & & \\
\hline & ion & & & & & & & & & & & & \\
\hline & Sig. (2- & .937 & & .000 & .000 & .279 & .155 & .198 & .060 & .068 & .000 & .496 & .234 \\
\hline & tailed) & & & & & & & & & & & & \\
\hline & $\mathrm{N}$ & 334 & 334 & 334 & 334 & 334 & 334 & 334 & 334 & 334 & 334 & 334 & 334 \\
\hline \multirow{6}{*}{$\begin{array}{l}\text { proficien } \\
\text { cy_2_AT } \\
\mathrm{T}\end{array}$} & Pearson & -.006 & $.448^{* *}$ & 1 & $-.124^{*}$ & $.119^{*}$ & .084 & -.098 & -.041 & $-.108^{*}$ & $.189^{*}$ & $.121^{*}$ & $.160^{* *}$ \\
\hline & Correlat & & & & & & & & & & * & & \\
\hline & ion & & & & & & & & & & & & \\
\hline & Sig. (2- & .908 & .000 & & .023 & .029 & .125 & .073 & .460 & .048 & .001 & .028 & .003 \\
\hline & tailed) & & & & & & & & & & & & \\
\hline & $\mathrm{N}$ & 334 & 334 & 334 & 334 & 334 & 334 & 334 & 334 & 334 & 334 & 334 & 334 \\
\hline \multirow{6}{*}{$\begin{array}{l}\text { proficien } \\
\text { cy_3_AT } \\
\text { T }\end{array}$} & Pearson & $.108^{*}$ & $-.214^{* *}$ & $-.124^{*}$ & 1 & -.032 & .064 & $-.117^{*}$ & - & $.122^{*}$ & .104 & .011 & -.089 \\
\hline & Correlat & & & & & & & & $.153^{* *}$ & & & & \\
\hline & ion & & & & & & & & & & & & \\
\hline & Sig. (2- & .048 & .000 & .023 & & .557 & .242 & .032 & .005 & .026 & .059 & .845 & .106 \\
\hline & tailed) & & & & & & & & & & & & \\
\hline & $\mathrm{N}$ & 334 & 334 & 334 & 334 & 334 & 334 & 334 & 334 & 334 & 334 & 334 & 334 \\
\hline
\end{tabular}




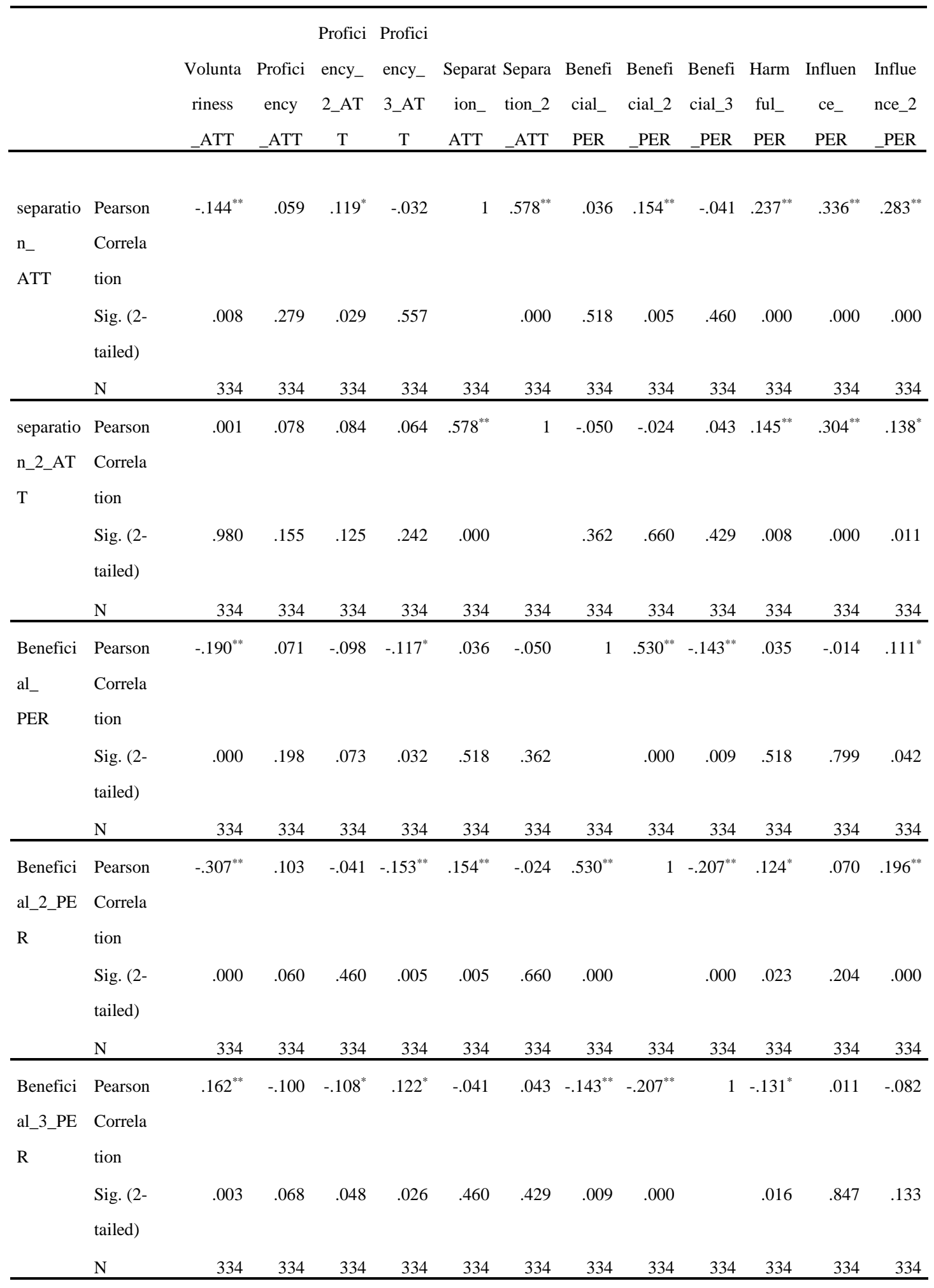




\begin{tabular}{|c|c|c|c|c|c|c|c|c|c|c|c|c|c|}
\hline & & & & Profic & Profic & & Separ & & & & & & \\
\hline & & $\begin{array}{c}\text { Voluntar } \\
\text { iness }\end{array}$ & $\begin{array}{l}\text { Profic } \\
\text { iency }\end{array}$ & $\begin{array}{l}\text { iency_ } \\
\text { 2_AT }\end{array}$ & $\begin{array}{l}\text { iency_ } \\
\text { 3_AT }\end{array}$ & $\begin{array}{c}\text { Separat } \\
\text { ion_ }\end{array}$ & $\begin{array}{l}\text { ation_ } \\
\text { 2_AT }\end{array}$ & $\begin{array}{c}\text { Benefi } \\
\text { cial_ }\end{array}$ & $\begin{array}{l}\text { Benefi } \\
\text { cial_2 }\end{array}$ & $\begin{array}{l}\text { Benefi } \\
\text { cial_3 }\end{array}$ & $\begin{array}{l}\text { Harm } \\
\text { ful_ }\end{array}$ & $\begin{array}{c}\text { Influen } \\
\mathrm{ce}_{-}\end{array}$ & $\begin{array}{l}\text { Influe } \\
\text { nce_2 }\end{array}$ \\
\hline & & ATT & _ATT & $\mathrm{T}$ & $\mathrm{T}$ & ATT & $\mathrm{T}$ & PER & PER & _PER & PER & PER & PER \\
\hline \multirow[t]{6}{*}{ harmful } & Pearson & $-.113^{*}$ & $.296^{* *}$ & $.189^{* *}$ & .104 & $.237^{* *}$ & $.145^{* *}$ & .035 & $.124^{*}$ & $-.131^{*}$ & 1 & .004 & -.027 \\
\hline & Correlati & & & & & & & & & & & & \\
\hline & on & & & & & & & & & & & & \\
\hline & Sig. (2- & .038 & .000 & .001 & .059 & .000 & .008 & .518 & .023 & .016 & & .939 & .628 \\
\hline & tailed) & & & & & & & & & & & & \\
\hline & $\mathrm{N}$ & 334 & 334 & 334 & 334 & 334 & 334 & 334 & 334 & 334 & 334 & 334 & 334 \\
\hline \multirow{6}{*}{$\begin{array}{l}\text { influenc } \\
\mathrm{e}_{-} \\
\text {PER }\end{array}$} & Pearson & $-.135^{*}$ & -.037 & $.121^{*}$ & .011 & $.336^{* *}$ & $.304^{* *}$ & -.014 & .070 & .011 & .004 & 1 & $.450^{* *}$ \\
\hline & Correlati & & & & & & & & & & & & \\
\hline & on & & & & & & & & & & & & \\
\hline & Sig. (2- & .013 & .496 & .028 & .845 & .000 & .000 & .799 & .204 & .847 & .939 & & .000 \\
\hline & tailed) & & & & & & & & & & & & \\
\hline & $\mathrm{N}$ & 334 & 334 & 334 & 334 & 334 & 334 & 334 & 334 & 334 & 334 & 334 & 334 \\
\hline \multirow{6}{*}{$\begin{array}{l}\text { influenc } \\
\text { e_2_PE } \\
\text { R }\end{array}$} & Pearson & $-.131^{*}$ & .065 & $.160^{* *}$ & -.089 & $.283^{* *}$ & $.138^{*}$ & $.111^{*}$ & $.196^{* *}$ & -.082 & -.027 & $.450^{* *}$ & 1 \\
\hline & Correlati & & & & & & & & & & & & \\
\hline & on & & & & & & & & & & & & \\
\hline & Sig. (2- & .017 & .234 & .003 & .106 & .000 & .011 & .042 & .000 & .133 & .628 & .000 & \\
\hline & tailed) & & & & & & & & & & & & \\
\hline & $\mathrm{N}$ & 334 & 334 & 334 & 334 & 334 & 334 & 334 & 334 & 334 & 334 & 334 & 334 \\
\hline
\end{tabular}

*. Correlation is significant at the 0.05 level (2-tailed). **. Correlation is significant at the 0.01 level (2-tailed). 
The results show a negative correlation between students who thought there was more they could learn about using social media and the perception of not being professionally benefitted from social media. In other words, if a student believes that they should learn more about social media, they don't find it as professionally beneficial $(\mathrm{r}=$ $.117, \mathrm{p}=.028)$. Similarly, there was a positive correlation between students who believed there is more they could learn about using social media and perceiving not using social media in the classroom as beneficial. Essentially, if a student feels like they have to learn more about social media, they would rather not have it in the classroom $(\mathrm{r}=.112, \mathrm{p}=$ .026).

Finally, there was a significant positive correlation between student's willingness to engage is social media if they had a separate account and the student's perception that they could not be themselves knowing their social media account is being viewed by an authority figure $(\mathrm{r}=.138, \mathrm{p}=.011)$. 


\section{DISCUSSION}

The focus of this study was to gain a deeper understanding of the attitudes that students hold about using social media in the classroom. After finding out what attitudes student held, the study wanted to see if those attitudes affected how they perceived instructors who choose to use social media in their classrooms. The theoretical approach to these questions used the theory of planned behavior, a theory which helps to understand how a behavior is changed or reinforced. The TPB has been highly influential, suggesting that performance of a behavior follows from attitudes, perceptions of control, and subjective norms (Ajzen \& Fishbein, 2005).

This study focused on two research questions. The first question sought to find out what student attitudes towards using social media in classes are and why they hold those attitudes.

$R Q$ 1: What are college student attitudes towards using social media professionally in classes?

This question answered the first consideration of the TPB. With regards to attitudes, students do hold positive attitudes about using social media, though there are some who do not. The existing literature shows that social media, when used as a learning tool, does provide educational benefits (Bicen, 2014; Ha \& Shin, 2014; Wang et. al; 2014). One study conducted by Merle and Freberg (2016) showed the presence of a social media assignment positively influenced the likelihood of the student registering for 
the course. While these studies show the benefits of using social media as a tool, the findings of the current study bolsters those findings by providing reasons behind why students hold those positive attitudes. However, Ajzen and Gilbert (2008) noted that sometimes, even when individuals hold strong attitudes, it does not always predict specific behavior. In the case of this study, the specific behavior is the positive perception of instructors using social media. Though students hold positive attitudes toward using social media, those positive attitudes are not enough to predict that the perceptions of instructors using social media will be positive. This should not lead to the conclusion that students will hold negative perceptions. Instead, this should cause instructors to consider how they approach education and social media.

It is important to point out that not all students held positive attitudes about using social media in the classroom. There were some students who were completely opposed to using social media. These students believe social media to be a distraction and takes away from what one student calls, "true communication." It is interesting to observe these students making the argument that social media has no place in the classroom, but still agreeing that it is an important part of the current world. These arguments are not far-fetched. Technology has regularly been associated with distractions. For example, Fried (2006) found that students who use laptops in-class spent considerable time multitasking and that the laptop use posed a significant distraction to both users and fellow students. The students who were completely opposed to using social media in the classroom took issue with social media already being a distraction to everyday interactions among individuals. To them, intentionally bringing distractions into the classroom was unacceptable. The reasons provided by these students were due to 
perceiving social media as a distraction that takes away from "true communication" or the student was not raised with social media, therefore did not see any value in it.

While majority of the focus group participants claimed to have a positive attitude about using social media, the primary caveat for students is the need for control over their use, as shown by the desire for voluntary use which leads to the second consideration of the theory of planned behavior, the perceptions of control.

Voluntariness of participation speaks to one of the considerations that make the theory of planned behavior, the control beliefs. Control beliefs speak toward the level of ease an individual might have toward performing a given action. In a study about leisure participation, Ajzen and Driver (2009) found that "participation in leisure activities were dependent upon normative beliefs about the expectations of important others and by control beliefs about required resources.” This study's conclusion is echoed in the responses of the students of the current study where their willingness to participate depends on their control beliefs about required sources in using social media. Along those same lines, the responses showed that students who felt like they had more to learn about social media found it less beneficial to use social media in class. This also reflects the consideration of control beliefs of the TPB. If a student feels like they are not well equipped to engage with a class via social media, their level of perceived control will be lower than a student who might be confident in using social media. This claim is supported by the data found in the survey which showed that students who felt like they know more about social media than their instructors understand the benefits of using social media and viewed not using social media as less beneficial. 
The third consideration of the TPB are the subjective norms about performing an action. The results of this study found no influence of subjective norms on using social media and its effect of student perceptions. However, the importance of understanding the influence of subjective norms should not be overlooked. Manning (2011) conducted a study which found that norms only directly influenced behaviors where rejection was made salient. This finding should cause instructors to consider the norm they set in their classrooms about using social media. While instructors do not have the ability to create or destroy norms about using social media on a universal level, they do have the ability to set the norms of the classrooms they belong in. Manning's result show that rejection of a norm can influence behavior. If that is the case, then, if the instructor wants to cause an increase in the use of social media and retain positive perceptions by the students, instructors must not reject students who are forthcoming about their use of social media. In setting the norm for their classroom about using social media, while allowing student participation to be voluntary combined with the positive attitudes that students hold, the instructor could create a positive perception of them using social media.

Another study reviewing the influence of norms on behavioral action was done by Zhou, Horrey, and Yu (2009) where they examined the intentions of pedestrians walking through traffic in China. They found that pedestrians reported greater likelihood in crossing the road when other pedestrians were crossing the road, reinforcing the influence of social norms on performing a given action. It is vital to note that for an action to be performed, a combination of the three consideration might have to occur. Zagata (2012), examining the intention to purchase organic food found the best predictors of the 
intention were attitudes toward the behavior and the subjective norms of performing the behavior.

The answer to the first research question was reiterated in the findings of the second research question. The second question wanted to see if the student attitudes affected how students perceived instructors who used social media.

$\boldsymbol{R} \boldsymbol{Q} 2$ : Do student attitudes towards social media affect their perception of a professor using social media for class?

To answer this question, a survey was conducted. In the survey, a series of questions were asked in the form of a 5 point Likert scale, ranging from strongly agree to strongly disagree. To calculate the correlation between student attitudes and student perception, attitudes was measured by posing a series of questions focused on voluntariness, proficiency, and separation. It is assumed that students had positive attitudes about using social media if they agreed on the following: (1) it was voluntary, (2) they felt themselves proficient in using social media, (3) they were given the freedom to create a separate account for classroom use, and (4) they did not feel using social media was an invasion of their privacy. Perception of social media use was measured based on questions focused on effects on the student/instructor relationship, influence on social media posts, benefits, and harmfulness of using social media. The TPB justifies the findings of the survey, reinforcing the responses to the first research question.

This research question asked if student attitudes affected how they perceive the use of social media in the classroom. The survey showed that students did hold positive attitudes toward using social media. To reinforce the assumption of attitudes having an influence on performing an action, Zikic and Saks (2009) conducted a study using the 
TPB examining if attitudes had any effect on the intention to search for jobs. They found that one of the influences higher job search intensity are the attitudes the seeker has toward the job search. Similarly, for students to be more engaged with social media in their classes, they need to have a positive attitude about using social media. Zhang et al. (2015) showed that attitudes and perceived behavioral control were important considerations to enact change on student intentions. Based on the results of the study, the positive attitudes held by the students is based on the idea of voluntariness. First, students argued that for them to engage with social media with their class, they should be given the option to create a separate account specifically for the class. Students expressed the need to control who views their posts and who they added to their social networking profiles. If students were forced to use their personal accounts, they would lose that control, negatively affecting how they would feel toward using social media in the classroom. In order for them to be positively inclined to engage with their class via social media, they need to be provided the choice to separate their personal space with their professional space. The survey conducted also reflected a correlation between students who would voluntarily engage with the class and how they perceived their instructors. There was a negative correlation found between students who voluntarily engage in social media and the effect it could have on the formality between students and instructors. In other words, the relationship between student and the teacher is less likely to become informal, if the student voluntarily engages with them online. This is a predictable conclusion, if the student can create a separate online account to use only for the class. Then the interactions between the instructor and the student will remain professional. There will not be information shared that are personal in nature (such as 
photos, political ideologies) that could influence the relationship. In this regard, the social media platform becomes just another channel of communication, much like e-mails or phone calls.

To provide more support showing the influence of attitudes and perceived behavioral control on intention to perform a behavior, Yang (2012), conducted a study on cheating behavior in business students which found attitudes, subjective norms, and perceived behavioral control to be positively associated with the intention to cheat and cheating behavior. Specifically, the noted that subjective norms could impact significantly on attitude and that perceived behavioral control had a direct effect on cheating behavior.

The second way voluntariness affected perception involved influence over social media posts. There was a negative correlation found between the two variables. This finding is not unexpected. If students are given the choice to use social media, then they are not obligated to connect with their peers or their instructors online. Students end up having the freedom to post whatever they want online knowing they do not have to be held accountable since their posts are not viewed by the people they are not connected to online. This correlation is reiterated when students were asked if they felt they cannot be themselves. The negative correlation found suggest that since voluntariness can lead to students not having to connect with their instructors, they do not feel like they cannot be themselves online.

The third and most interesting finding is how voluntariness affected perception of social media as a distraction. Only 1.68 percent of the 334 participants disagreed with the notion that social media is a distraction while 84.63 percent of the participants agreed that 
it was. It is difficult to disagree with these students, since social media platforms have grown to be far more than just platforms to connect with others. Social Networking Sites have become an entire entity centered around quick, small interactions like comments, or likes, or retweets. Notification technologies on smartphones have grown to the point where every time an individual is tagged anywhere and at any time, they are notified immediately, forcing them to be distracted from what they may doing at any given moment. However, when calculating the correlation between voluntariness and viewing social media as a distraction, the response show that students who voluntarily use social media do not perceive social media as much of a distraction. While this is an interesting correlation, there is a potential explanation for why this correlation exists. Simply put, if students are opting to not use social media in the classroom they will not get distracted and therefore do not perceive social media as a distraction.

If voluntary participation has the potential to lead to positive perception of instructors using social media, then instructors need to evaluate why they are using social media. Voluntary participation of social media is most likely what can lead to students being the truest version of who they are when engaging with the class. While there may not be anything wrong with students creating a separate account to engage with the class, the effectiveness of that would be based on the effort the student is willing to put forth to maintain both profiles.

This is reiterating what was found under the first research question involving the TPB. The survey found positive perceptions of instructor social media use was largely tied to their perceived behavioral control over using social media in the classroom. Based on the theory, perceived behavioral control is one of the variables that affect behavioral 
intention or the intent to perform a given action. Therefore, if the goal is to have the student positively perceive the instructor who uses social media, the student needs to voluntarily engage in the with the instructor online. The combination of the three considerations that make the TPB, attitude toward the behavior, subjective norm, and the perception of behavioral control leads to the formation of a behavioral intention (Ajzen, 2002). Ajzen (2002) claims that if the individual is given sufficient actual control over a behavior, then the individual will perform the behavior when the opportunity arises. The students who volunteer to use social media hold a certain amount of perceived control over their behavior. According to Ajzen (2002), this would lead them to have a behavior, which in this case, is a positive perception of instructors using social media. The results of this study support that claim.

It should also be noted that all the correlations found, while statistically significant, was not strong enough to assume that a positive attitude automatically leads to positive perceptions.

There were no significant correlations found between students who believed they did not need to be taught about social media and how they perceived instructors using social media in the classroom. Students who feel like they already know a subject or know the content tend to be indifferent to having to engage or participate in that subject. However, it should be a point of note that these students who felt proficient enough to admit they do not need to be taught how to use social media did not express a positive perception to using social media. This lack of significance challenges the idea that familiarity and comfort with something equates to a willingness to participate in it professionally. There was also no statistical significant correlation between students who 
preferred to separate their personal and professional social media accounts and their perception of using social media in the classroom. This is also an important observation to make because it contests the idea that offering the freedom from the invasion of personal space of a student's private social media account is not a solution for students who may not perceive using social media in the classroom as a positive idea.

There were significant correlations found between the voluntary participation in social media and the branches measuring perception of social media use. First, there was negative correlation between voluntariness and online interactions becoming more informal. In other words, this negative correlation is stating that the more voluntary social media participation is, it is less likely that the relationship between instructor and student will become informal. Therefore, if the participation was voluntary and students were offered the option to create a separate account, the relationship with their instructor could remain just as formal as it is in the classroom, with the social media simply providing another way to connect with the instructor, like an email address or a phone number.

There were negative correlations also found between voluntariness and both statements measuring perceptions based on influence. In other words, if students were to participate voluntarily with social media their posts would not be affected much knowing their professors could view them. This is a predictable correlation. If students are voluntarily engaging in social media, they wouldn't post anything online they do not feel comfortable anyone, including their instructor, seeing. Due to this, students who voluntary engage in social media does not run into the obstacle of feeling like they can't be themselves online. Yet another predictable correlation is between correlation and perceiving social media as a distraction. Students who choose to engage in social media 
is less likely to view social media as a distraction. This might be because if they plan on using social media for their class, they are intentionally doing so, with a willingness to accomplish the task they set out to complete. On the other hand, if students are forced to used social media, their focus may not be entirely on what the task is, which can lead them to getting distracted and hence perceiving social media as a distraction

Students who saw themselves as having more to learn about social media did not see any professional benefit to using it. The TPB explain this relationship. Control beliefs, or the perceived behavioral control that individuals believe that they hold can affect how they behave toward it. In this case, if a student perceives the use of social media as difficult (or they have to learn how to use social media) their perceived control is lower than if the student felt confident in using it. Students who feel like they have more to learn about the technology are students who probably do not engage constantly with it, and they may already have preconceived notions about social media. They may already hold ideas about it not being beneficial. But their admittance that they have more to learn about social media does not necessarily come from a desire to become more familiar with the medium. Rather, these are the students who realize that social media is a huge part of today's working climate and believe that they have more to learn about it. These students are those who personally might not see a benefit in social media but are also aware of the presence of social media in the world today.

While perceived control is important to students, the TPB has two more considerations that instructors should consider in order to gain a positive perception of using social media. These other two considerations are the attitudes and subjective norms (Ajzen, 1991). Considering attitudes, the findings show that students have positive 
attitudes toward using social media and existing literature on the TPB show that positive attitudes have a positive effect on the performance of a given behavior. Instructors intending to use social media in their classrooms will have to consider ways to maintain positive attitudes toward using social media. Along those lines, instructors may have to focus on establishing a norm of using social media to the extent that students assume using social media in the classroom as a normative behavior.

Which leads to this conclusion: if the instructor can successfully continue to foster positive attitudes about using social media (attitudes), establish a norm within the classroom about using social media (normative beliefs), and give the students control over having to use social media in the classroom (control beliefs), the combination of these three aspects could lead to students holding positive perceptions of instructors who use social media in the classroom. 


\section{CONCLUSION}

The primary goal for this study was understanding the attitudes students hold about using social media and why they hold the attitudes that they do. The theory of planned behavior provided a justification for these results. The findings of this study show the importance of the first two considerations of the TPB and a suggestion is made for the third.

Based on the existing literature (Ajzen, 1991; Ajzen, 2002; Ajzen \& Driver, 2009; Zagata, 2012; Zhang et al., 2015; Zhou et. al 2009; Zikic \& Saks, 2009) all three considerations that make the theory of planned behavior: attitudes, subjective norms, and perceived behavioral control, can influence the likelihood of the performance of a behavior. Students have positive attitudes about using social media, because they see social media as the way of the future. However, these attitudes are not universally held by student. Instructors need to pay attention to the fact that some students do not like using social media. This does not mean instructors should not use social media. Instead, understanding student's negative attitudes can allow for instructors to mold how they approach either teaching social media or how they use social media in the class. The main take away for instructors is students do have a positive attitude, but only to the extent that they voluntarily choose to participate, transitioning to the second consideration of the TPB. 
The instructor should put effort into focusing on the benefits that social media can afford, but ultimately leave the choice of participation to the student. The primary findings on voluntariness show that students have a certain level of knowledge about using social media and they want that knowledge to be respected. Instructors then need to determine a way to navigate a student body that is familiar with use of the technology. Instructors might need to consider teaching social media theoretically rather than application.

While the results show no influence of subjective norms on the performing of an action, norms still influence the likelihood of performing a behavior (Yang, 2012). Instructors should consider creating an environment of accepted social media use for students to feel comfortable in engaging with it in the class. If an instructor can successfully create a standard in the classroom of using social media, students might engage more via social media, if the students around them are also using it in the class.

Ultimately, the implications of this study come down to the intent of the instructor in using social media. If the instructor is using social media to show students how to use an application, students might not receive that well because they already have a familiarity with the application. If the instructor simply wants to offer the use of social media as another communication channel, then students must be given the option to connect through social media rather than being forced to use it. However, if the instructor wants to teach students to use social media to enhance the classroom educational experience, then instructors must find a creative way to approach using social media in the classroom. The instructor must then, push into the positive attitudes students hold, set a norm of using social media, and provide the students with a choice to participate. 


\section{LIMITATIONS AND FUTURE RESEARCH}

There were a few limitations facing the current study that should be considered in future research. First, this study used a convenient sample of students, gathering participants only from one university. Second, the students who participated in the study were all students who took traditional classes (i.e. in person). Third, all the participants were also only undergraduate students.

Future research done looking at this topic should consider using a more varied sample of students. Students primarily taking online classes should also be considered to see if it has an effect on the results.

Future research should also consider focusing on comparing student attitudes to instructor attitudes toward integrating social media into the classroom. Opportunities to compare attitudes of students who use social media professionally with students who do not use social media professionally should be considered. 


\section{REFERENCES}

A Brief History of LinkedIn. (n.d.). Retrieved March 28, 2017, from

https://ourstory.linkedin.com/

Ajzen, I. (2002). Perceived Behavioral Control, Self-Efficacy, Locus of Control, and the Theory of Planned Behavior¹. Journal Of Applied Social Psychology, 32(4), 665683. doi:10.1111/j.1559-1816.2002.tb00236.x

Ajzen, I., \& Gilbert Cote, N. (2008). Attitudes and the prediction of behavior. In W. D. Crano \& R. Prislin (Eds.), Attitudes and attitude change (pp. 289-311). New York: Psychology Press.

Al-Bahrani, A., Patel, D., \& Sheridan, B. (2015). Engaging students using social media: The students' perspective. International Review of Economics Education, 19, 3650. doi:10.1016/j.iree.2015.06.001

Al-Bahrani. A. \& Patel. D. (2015) Incorporating Twitter, Instagram, and Facebook in Economics Classrooms, The Journal of Economic Education, 46:1, 56-67, DOI: $10.1080 / 00220485.2014 .978922$

Ajzen, I. (1985). From intentions to actions: A theory of planned behavior. In J. Kuhl \& J. Beckman (Eds.), Action-control: From cognition to behavior (pp. 11-39). Heidelberg: Springer.

Ajzen, I. (1991). The theory of planned behavior. Organizational Behavior and Human 
Decision Processes, 50, 179-211

Ajzen, I., \& Fishbein, M. (2005). The influence of attitudes on behavior. In D.

Albarracín, B. T. Johnson, \& M. P. Zanna (Eds.), The handbook of attitudes (pp. 173-221). Mahwah, NJ: Erlbaum

Bicen, H. (2014). Student Opinions Regarding Twitter Usage with Mobile Applications for Educational Purposes. Procedia - Social and Behavioral Sciences, 136, 385390. doi:10.1016/j.sbspro.2014.05.345

Carlson, N. (2010, March 05). At Last -- The Full Story Of How Facebook Was Founded. Retrieved March 28, 2017, from http://www.businessinsider.com/how-facebookwas-founded-2010-3

Dabbagh, N., \& Kitsantas, A. (2012). Personal Learning Environments, social media, and self-regulated learning: A natural formula for connecting formal and informal learning. The Internet And Higher Education, 15(1), 3-8.

doi:10.1016/j.iheduc.2011.06.002

Davies, T. L., Lavin, A. M., \& Korte, L. (n.d.). Student Perceptions of How Technology Impacts the Quality of Instruction and Learning. Journal of Instructional Pedagogies, 2-16. Retrieved from http://www.aabri.com/manuscripts/08015.pdf

DeAndrea, D. C., Ellison, N. B., LaRose, R., Steinfield, C., \& Fiore, A. (2012). Serious social media: On the use of social media for improving students' adjustment to college. The Internet And Higher Education, 15(1), 15-23.

doi:10.1016/j.iheduc.2011.05.009

Deil-Amen, R., PhD, Rios-Aguilar, C., PhD, Davis, C. H., III, \& Canche, M. S. (n.d.). Social Media in Higher Education: A Literature Review and Research Directions. 
Retrieved September 06, 2016, from

http://www.academia.edu/1220569/Social_Media_in_Higher_Education_A_Liter

ature_Review_and_Research_Directions

Eagly, A. H., \& Chaiken, S. (1993). The psychology of attitudes. Fort Worth: Harcourt Brace Jovanovich.

Fife, E. M. (2007). Using Focus Groups for Student Evaluation of Teaching. Retrieved March 28, 2017, from http://mountainrise.wcu.edu/index.php/MtnRise/article/viewFile/78/41

Fried, C. B. (2008). In-class laptop use and its effects on student learning. Computers \& Education, 50(3), 906-914. doi:10.1016/j.compedu.2006.09.006

Greenwood, S., Perrin, A., \& Duggan, M. (2016, November 11). Social Media Update 2016. Retrieved March 28, 2017, from http://www.pewinternet.org/2016/11/11/social-media-update-2016/

Ha, J., \& Shin, D. H. (2014). Facebook in a Standard College Class: An Alternative Conduit for Promoting Teacher-Student Interaction. American Communication Journal, 16(1), 36-52. Retrieved September 6, 2016, from http://content.ebscohost.com.echo.louisville.edu/ContentServer.asp?T=P\&P=AN $\underline{\& K}=97065128 \& \mathrm{~S}=\mathrm{R} \& \mathrm{D}=\mathrm{ufh} \&$ EbscoContent=dGJyMNLr40SeprQ40dvuOLCmr 06ep7VSsKi4SrGWxWXS\&ContentCustomer=dGJyMPGqs0u0rrVPuePfgeyx44 $\underline{\text { Dt6fIA }}$

Hays, C. B. (2008). The Silence of the Wives: Bakhtin's Monologism and Ezra 7--10. Journal for the Study of the Old Testament, 33(1), 59-80. doi:10.1177/0309089208094460 
Hennessy, S., Wishart, J., Whitelock, D., Deaney, R., Brawn, R., la Velle, L., McFarlane A., Ruthven K., Winterbottom, M. (2007). Pedagogical approaches for technology-integrated science teaching. Computers \& Education, 48(1), 137-152. doi:10.1016/j.compedu.2006.02.004

Hrastinski, S., \& Dennen, V. (2012). Social media in higher education: Introduction to the special issue. Internet \& Higher Education, 15(1).

Hunter, J. D., \& Caraway, H. J. (2014, March). Urban Youth Use Twitter to Transform Learning and Engagement. English Journal, 76-82. Retrieved from http://www.ncte.org/library/NCTEFiles/Resources/Journals/EJ/1034$\underline{\text { mar2014/EJ1034Urban.pdf }}$

Incantalupo, L., Treagust, D. F., \& Koul, R. (2013). Measuring Student Attitude and Knowledge in Technology-Rich Biology Classrooms. Journal of Science Education and Technology, 23(1), 98-107. doi:10.1007/s10956-013-9453-9

Katz, D. (1960). The Functional Approach to the Study of Attitudes. The Public Opinion Quarterly,24(2), 163-204. Retrieved from http://www.jstor.org/stable/2746402

Kolitch, E., \& Dean, A. V. (1999). Student ratings of instruction in the USA: Hidden assumptions and missing conceptions about "good" teaching. Studies in Higher Education, 24, 27-42.

Laru, J., Näykki, P., \& Järvelä, S. (2012). Supporting small-group learning using multiple Web 2.0 tools: A case study in the higher education context. The Internet And Higher Education, 15(1), 29-38. doi:10.1016/j.iheduc.2011.08.004 
Levin, T., \& Wadmany, R. (2008). Teachers' Views on Factors Affecting Effective Integration of Information Technology in the Classroom: Developmental Scenery. Journal Of Technology \& Teacher Education, 16(2), 233-263.

Merle, P., \& Freberg, K. (2016). All about that tweet: Student perceptions of professors' social media use in the classroom. Journal of Research in Interactive Marketing, 10(2), 124-136. doi:10.1108/jrim-01-2015-0008

Mikhail Bakhtin. (2016). In Encyclopædia Britannica. Retrieved from https://www.britannica.com/biography/Mikhail-Bakhtin

Myhill, D. and Fisher, R. (2005) Informing practice in English: A review of recent research in literacy and the teaching of English. London: Her Majesty's Inspectorate.

Novak, E., Razzouk, R., \& Johnson, T. E. (2012). The educational use of social annotation tools in higher education: A literature review. The Internet And Higher Education, 15(1), 39-49. doi:10.1016/j.iheduc.2011.09.002

Orlando, M. (2013). Nine Characteristics of a Great Teacher. (2016). Retrieved September 06, 2016, from http://www.facultyfocus.com/articles/philosophy-ofteaching/nine-characteristics-of-a-great-teacher/

Perrin, A. (2015). Social Media Usage: 2005-2015. Retrieved September 13, 2016, from http://www.pewinternet.org/2015/10/08/social-networking-usage-2005-2015/

Rosen, L. D., Whaling, K., Carrier, L. M., Cheever, N. A., \& Rokkum, J. (2013). The Media and Technology Usage and Attitudes Scale: An empirical 
investigation. Computers In Human Behavior, 29(6), 2501-2511.

doi:10.1016/j.chb.2013.06.006

Ross M, Morrison GR, Lowther D (2010) Educational technology research past and present: balancing rigor and relevance to impact school learning. Contemp Educ Technol 1(1):17-35

Schroeder, C. M., Scott, T. P., Tolson, H., Huang, T.-Y. and Lee, Y.-H. (2007), A metaanalysis of national research: Effects of teaching strategies on student achievement in science in the United States. J. Res. Sci. Teach., 44: 1436-1460. doi:10.1002/tea.20212

Smith, A., Rainie, L., \& Zickuhr, K. (2011, July 18). College students and technology. Retrieved March 21, 2017, from http://www.pewinternet.org/2011/07/19/college$\underline{\text { students-and-technology/ }}$

Social Media Fact Sheet. (2017, January 12). Retrieved March 28, 2017, from http://www.pewinternet.org/fact-sheet/social-media/

Tang, T. L., \& Austin, M. J. (2009). Students' perceptions of teaching technologies, application of technologies, and academic performance. Computers \& Education, 53(4), 1241-1255. doi:10.1016/j.compedu.2009.06.007

Twitter turns six | Twitter Blogs. (2012). Retrieved March 28, 2017, from https://blog.twitter.com/2012/twitter-turns-six

United States Department of Education (2010) Office of Education Technology, transforming American education: learning powered by technology. Draft national education technology plan 2010. Executive summary, Washington DC. 
Retrieved October 08, 2016 http://ed.gov/technology/netp-2010/learning-engageand-empower

Wang, Q., Woo, H. L., Quek, C. L., Yang, Y., \& Liu, M. (2011). Using the Facebook group as a learning management system: An exploratory study. British Journal of Educational Technology, 43(3), 428-438. doi:10.1111/j.1467-8535.2011.01195.x

Ward, L., \& Parr, J. M. (2010). Revisiting and reframing use: Implications for the integration of ICT. Computers \& Education, 54(1), 113-122. doi:10.1016/j.compedu.2009.07.011

Wodzicki, K., Schwämmlein, E., \& Moskaliuk, J. (2012). “Actually, I Wanted to Learn”: Study-related knowledge exchange on social networking sites. The Internet And Higher Education, 15(1), 9-14. doi:10.1016/j.iheduc.2011.05.008

Yang, J. (2012). Predicting cheating behavior: A longitudinal study with Chinese business students. Social Behavior and Personality, 40(6), 933-944

Zagata, L. (2012). Consumers' beliefs and behavioral intentions towards organic food. Evidence from the Czech Republic. Appetite, 59(1), 81-89.

Zhang, N., Campo, S., Yang, J., Janz, K. F., Snetselaar, L. G., \& Eckler, P. (2015). Effects of social support about physical activity on social networking sites: Applying the theory of planned behavior. Health Communication, 30(12), 12771285.

Zhou, R., Horrey, W. J., \& Yu, R. (2009). The effect of conformity tendency on pedestrians' road-crossing intentions in China: An application of the theory of planned behavior. Accident Analysis \& Prevention, 41(3), 491-497. 
Zikic, J., \& Saks, A. M. (2009). Job search and social cognitive theory: The role of career-relevant activities. Journal of Vocational Behavior, 74, 117-127. 


\section{APPENDICES}

Appendix A: Focus Group Questions

\section{Grand tour questions}

1. I'd like to start by asking about your first reaction to learning that we are here in the focus group to talk about using social media for class.

○ (Ask follow-up questions, such as why)

2. How would you describe your level of interest in using social media for class, as compared to other class assignments in general?

(Ask follow-up questions, such as why)

3. Explain the process that you went through in a class that used social media.

- How long did you all do this for the semester? What was the portion of your grade for the class with this assignment?

\section{Instructors and Social Media Use in the Classroom}

1. How confident did you feel as you were in using social media for class? Why?

a. How confident would you feel if you were asked to use social media professionally in the workplace? Please explain.

b. What would your advice be to future students who are asked to use social media for class?

c. What is the value of using social media class have to you? 
2. How do you think instructors should prepare students for the continuous growth of social media/personal branding expected by organizations looking to hire employees?

a. Do you think this assignment will help you get an internship or full-time job? Why or why not?

b. Do you think this assignment will help you once you're in an internship or full-time job? Why or why not?

3. Question about voluntariness.

\section{Have you had instructors who have used Social Media in any of your classes?}

1. What do you think the general attitudes are about instructors who use social media in the classroom?

2. (If no) Would you have liked using SM? Why or why not?

3. (If yes) Did you like using SM in the class? Why did you like it? Why not? What were the challenges and opportunities in using SM?

4. (If yes) What platform did you all use in class? What platform would you have liked to have used? Please explain.

5. What did you learn from the exercise / use of social media for class?

○ How did this assignment affect your research / writing skills (if it did)?

○ How did this assignment affect your communication skills (if it did)?

- How did this assignment affect your critical thinking skills?

- Are there any ways in which using social media for class went beyond what you have done with other assignments? How?

\section{Perceptions of professors and their use of SM for class}


1. Why do you think instructors would have their class use SM?

2. If the reason in using $\mathrm{SM}$ is to help you assimilate to growing technology, would you like more instructors to use SM?

3. How do you feel about the possibility of merging your social and professional lives if instructors would have you use SM that you are already using? Do you feel that to be advantageous or not?

How do you think SM might affect the relationship between student and instructor?

\section{Final questions (opportunities to ask the focus groups)}

1. Is there anything you would like to add? 
Appendix B: Survey

\section{General Information}

1. Name:

2. Gender (circle one): MALE FEMALE

3. Ethnicity (circle one):
a. White/Non-Hispanic
b. Black
c. White/Hispanic
d. Asian
e. Other (please specify):

4. Year of birth:

5. Course and section:

6. What is your current academic class standing?
a. Freshman
b. Sophomore
c. Junior
d. Senior

7. What is your intended major?

8. What college does your major belong to?
a. College of Law
b. College of Arts and Sciences
c. College of Business
d. College of Education
e. College of Health Professions
f. College of Informatics
g. Speed School
h. Have not Declared a Major

\section{General Questions about Social Media}

9. Rank the social Media networks that you use most often (starting with 1 for the most used network and 7 for the least used) and only rank the ones you use [Click and Drag the following options to order it per your use].

Facebook

Twitter

Pinterest 
Snapchat

Instagram

Youtube

Blogger

Reddit

Tumblr

LinkedIn

Other

10. How much time do you spend on Social Media?
a. Less than 1 hour
b. 1-2 hours
c. 2-3 hours
d. More than 3 hours

11. Other than Family and Friends, who else do you include in your social networks (Circle all that apply)
a. Celebrities
b. Politicians
c. Businesses (Stores)
d. Brands (like P\&G)
e. Influencers
f. Anonymous accounts
g. News agencies
h. Athletes and Sport teams
i. Professors
j. Universities
k. Other:

12. Do you think that professors should have a presence on social networks?
a. Yes
b. No

13. Would you include a professor into your social networks?
a. Yes
b. Maybe
c. No

14. If the previous answer is YES, what platform would you prefer to use to connect with your professor?

15. What is your biggest concern of including a faculty member on your social networks? (Rank from 1 as the biggest concern to 5 as the lowest concern) [Click and Drag the following options to order it per your concerns]. Pictures 
Inappropriate language

Behavior that professor might deem inappropriate

Socially unacceptable

Other

16. If social media was a voluntary part of class would you participate
a. Yes
b. No

\section{General Student Attitudes about using Social Media in Classroom [as an assignment or to interact with the instructor]}

17. I would register for a class with a professor who requires students to use social media for class activities.

$\begin{array}{lllllll}\text { Strongly } & 1 & 2 & 3 & 4 & 5 & \text { Strongly Disagree }\end{array}$

Agree

18. I do not want to register for a class with a professor who requires students to use social media for class activities.

$\begin{array}{lllllll}\text { Strongly } & 1 & 2 & 3 & 4 & 5 & \text { Strongly Disagree }\end{array}$

Agree

19. It is expected of me that I invest in my professional future career by taking classes with professors using social media will help me prepare for the growing expectations in the field.

$\begin{array}{lllllll}\text { Strongly } & 1 & 2 & 3 & 4 & 5 & \text { Strongly Disagree }\end{array}$

Agree

20. I believe that I am doing something positive for my professional future if I have to use social media for class.

$\begin{array}{lllllll}\text { Strongly } & 1 & 2 & 3 & 4 & 5 & \text { Strongly Disagree }\end{array}$

Agree

21. I do not think social media offers any benefit to me professionally.

$\begin{array}{lllllll}\text { Strongly } & 1 & 2 & 3 & 4 & 5 & \text { Strongly Disagree }\end{array}$

Agree

(For Questions $22 \& 23$, we want to see if you believe the use of social media as harmful or beneficial when incorporated in a classroom setting)

22. Overall, I think that using social media for class is: 

Harmful
1
2
45
Beneficial

23. Overall, I think that not having to use social media for this class is:

$\begin{array}{lllllll}\text { Harmful } & 1 & 2 & 3 & 4 & 5 & \text { Beneficial }\end{array}$

Separation of Personal and Professional Social Media Accounts [the following questions assumes you are in a class where you are asked to use Social Media]

24. Using my social media profile in the classroom is an invasion of my privacy

$\begin{array}{lllllll}\text { Strongly } & 1 & 2 & 3 & 4 & 5 & \text { Strongly Disagree }\end{array}$

Agree

25. I like to separate my personal social media account and my professional social media account

$\begin{array}{lllllll}\text { Strongly } & 1 & 2 & 3 & 4 & 5 & \text { Strongly Disagree }\end{array}$ Agree

26. I would use social media in class if I had a separate account

$\begin{array}{lllllll}\text { Strongly } & 1 & 2 & 3 & 4 & 5 & \text { Strongly Disagree }\end{array}$ Agree

27. I use my personal social media accounts for professional use as well

$\begin{array}{lllllll}\text { Strongly } & 1 & 2 & 3 & 4 & 5 & \text { Strongly Disagree }\end{array}$ Agree

28. My social media posts are affected if I know my professor can see them

$\begin{array}{lllllll}\text { Strongly } & 1 & 2 & 3 & 4 & 5 & \text { Strongly Disagree }\end{array}$ Agree

29. I don't like having my classmates view my social media posts

$\begin{array}{lllllll}\text { Strongly } & 1 & 2 & 3 & 4 & 5 & \text { Strongly Disagree }\end{array}$ Agree

30. I like having my classmates view my social media posts.

$\begin{array}{lllllll}\text { Strongly } & 1 & 2 & 3 & 4 & 5 & \text { Strongly Disagree }\end{array}$ Agree 


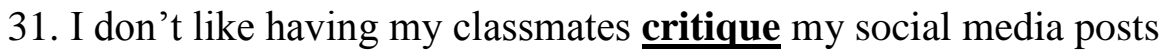

$\begin{array}{lllllll}\text { Strongly } & 1 & 2 & 3 & 4 & 5 & \text { Strongly Disagree }\end{array}$ Agree

32. I like having my classmates critique my social media posts

$\begin{array}{lllllll}\text { Strongly } & 1 & 2 & 3 & 4 & 5 & \text { Strongly Disagree }\end{array}$ Agree

33. I think my social media posts can benefit other students

$\begin{array}{lllllll}\text { Strongly } & 1 & 2 & 3 & 4 & 5 & \text { Strongly Disagree }\end{array}$ Agree

34. Instructors accessing my social media account is different than employers accessing my social media account

$\begin{array}{lllllll}\text { Strongly } & 1 & 2 & 3 & 4 & 5 & \text { Strongly Disagree }\end{array}$

Agree

35. I will be okay with allowing employers access to my social media account

$\begin{array}{lllllll}\text { Strongly } & 1 & 2 & 3 & 4 & 5 & \text { Strongly Disagree }\end{array}$

Agree

36. I will connect with my professor on social media after I graduate from their class

$\begin{array}{lllllll}\text { Strongly } & 1 & 2 & 3 & 4 & 5 & \text { Strongly Disagree }\end{array}$

Agree

37. I use social media to contact my classmates

$\begin{array}{lllllll}\text { Strongly } & 1 & 2 & 3 & 4 & 5 & \text { Strongly Disagree }\end{array}$

Agree

Effects on Student/Instructor Relationships [the following questions assumes you are in a class where you are asked to use Social Media]

38. I can't be myself if my social media can be seen by an authority figure

$\begin{array}{lllllll}\text { Strongly } & 1 & 2 & 3 & 4 & 5 & \text { Strongly Disagree }\end{array}$

Agree

39. The instructor cares about what you post on social media

$\begin{array}{lllllll}\text { Strongly } & 1 & 2 & 3 & 4 & 5 & \text { Strongly Disagree }\end{array}$ 
Agree

40. Your relationship with the instructor will be affected if you interact via social media

$\begin{array}{lllllll}\text { Strongly } & 1 & 2 & 3 & 4 & 5 & \text { Strongly Disagree }\end{array}$

Agree

41. Online interaction between student and instructor makes the relationship more informal

$\begin{array}{lllllll}\text { Strongly } & 1 & 2 & 3 & 4 & 5 & \text { Strongly Disagree }\end{array}$

Agree

\section{The Future}

42. Instructors use social media because they are trying to keep up with the future

$\begin{array}{lllllll}\text { Strongly } & 1 & 2 & 3 & 4 & 5 & \text { Strongly Disagree }\end{array}$ Agree

43. When you apply for jobs, employers will view your social media accounts

$\begin{array}{lllllll}\text { Strongly } & 1 & 2 & 3 & 4 & 5 & \text { Strongly Disagree }\end{array}$ Agree

44. Social media should only be used in specific courses

$\begin{array}{lllllll}\text { Strongly } & 1 & 2 & 3 & 4 & 5 & \text { Strongly Disagree }\end{array}$ Agree

45. Social media is a tool, but is also a distraction

$\begin{array}{lllllll}\text { Strongly } & 1 & 2 & 3 & 4 & 5 & \text { Strongly Disagree }\end{array}$ Agree

46. Social media negatively affects students' attention span

$\begin{array}{lllllll}\text { Strongly } & 1 & 2 & 3 & 4 & 5 & \text { Strongly Disagree }\end{array}$

Agree

47. I do not need to be taught how to use social media

$\begin{array}{lllllll}\text { Strongly } & 1 & 2 & 3 & 4 & 5 & \text { Strongly Disagree }\end{array}$

Agree 
48. I am more proficient in using social media than my instructors

Strongly

$\begin{array}{lllll}1 & 2 & 3 & 4 & 5\end{array}$

Strongly Disagree

Agree

49. There is more I could learn about using Social Media

Strongly

$\begin{array}{lllll}1 & 2 & 3 & 4 & 5\end{array}$

Strongly Disagree

Agree

50. Is there anything else you would like to add? 
Appendix C: Survey Informed Consent

\section{Subject Informed Consent Document}

Student perception of Social Media utilization by educators as classroom tools to increase classroom engagement.

Investigator(s) name \& address:

Abi John

Strickler Hall Room 310

Site(s) where study is to be conducted:

University of Louisville

Phone number for subjects to call for questions:

(502) 468-8889

Introduction and Background Information

You are invited to participate in a research study. The study is being conducted by University of Louisville, Masters Student Abi John. The study will take place within the University of Louisville. One hundred and twenty students have been invited to participated in the survey portion of this study and 20 students have been invited to participate in the focus group portion of this study.

\section{$\underline{\text { Purpose }}$}

This study can help educators understand the benefits of using Social Media as a classroom tools. Students are already engaging in various forms of Social Media (Facebook, Twitter, Snapchat etc.). Some of these platforms have educational potential and this study aims to see if educators should be encouraged to use this in their classrooms. This study will assess student attitudes about educators using Social Media for classroom purposes to evaluate if using Social Media in classroom should be encouraged.

\section{Procedures}

This study will have 4 focus groups with 5 undergraduate students from different backgrounds and different degrees in each group. This will help gain a deeper understanding of how students perceive use of social media in classrooms. The focus groups will also help create a survey to be conducted amongst a larger group of students to see how they feel about educators using Social Media in their classrooms. If the results show that students engage more with classroom activities by using Social Media, educators should be encouraged to use Social Media as classroom tools to potentially increase student class performance. 


\section{$\underline{\text { Methodology }}$}

You will take a survey that will measure your Social Media use along with your perception of educators who use Social Media as a classroom tool. The questions that are asked have been formed from focus groups that have been performed. The responses will be analyzed by the researcher through a mixed method approach. On the qualitative side, focus groups are going to be conducted in order to gain a rich understanding of students' attitudes on professional social media use in classroom. On the quantitative side, the responses found in the focus groups will be put through a survey of a larger sample size to see if the qualitative findings are generalizable.

\section{$\underline{\text { Benefits }}$}

This study can help educators by showing a potential way to increase classroom engagement. If students are already engaging with Social Media, then incorporating that as a tool in classrooms could provide a way for students to be more engaged in classrooms and potentially increase student performance.

\section{Compensation}

Students who participated in this focus group will be compensated for their time by being provided extra credit, the amount of which is based on the students' professor.

\section{Confidentiality}

The personal information of the student will be kept private, allowing only for the researcher to access. The information pertaining to the study, (ex: student Social Media use) and any other information given in the survey could be published in the final study and wherever the study may be published.

\section{Voluntary Participation}

While this experiment is voluntary, you are compensated for your time. You are encouraged to fully participate in this experiment. Your participation can help identify if there is any weight to encourage educators to utilize Social Media in their classrooms. This can be beneficial to both students as well as educators.

You will be made aware of any changes that may occur during the process of this study.

\section{Contact Information}

If you have any questions or concerns about this study or if you have any problems arise, please contact Abi John at the University of Louisville at 502-852-1111. If you have any questions or concerns about your rights as a research participant, please contact the University of Louisville Institutional Review Board at 502-852-1112.

\section{$\underline{\text { Consent }}$}


I agree to participate in this study: __ YES ___ N

Appendix D: Focus Group Informed Consent

\section{Subject Informed Consent Document}

Student perception of Social Media utilization by educators as classroom tools to increase classroom engagement.

Investigator(s) name \& address:

Abi John

Site(s) where study is to be conducted:

University of Louisville

Phone number for subjects to call for questions:

(502) 468-8889

\section{$\underline{\text { Introduction and Background Information }}$}

You are invited to participate in a research study. The study is being conducted by University of Louisville, Masters Student Abi John. The study will take place within the University of Louisville. 120 students have been invited to participated in the survey portion of this study and 20 students have been invited to participate in the focus group portion of this study.

\section{$\underline{\text { Purpose }}$}

This study can help educators understand the benefits of using Social Media as a classroom tools. Students are already engaging in various forms of Social Media (Facebook, Twitter, Snapchat etc.). Some of these platforms have educational potential and this study aims to see if educators should be encouraged to use this in their classrooms. This study will assess student attitudes about educators using Social Media for classroom purposes to evaluate if using Social Media in classroom should be encouraged.

\section{$\underline{\text { Procedures }}$}

This study will have 4 focus groups with 5 undergraduate students from different backgrounds and different degrees in each group. This will help gain a deeper understanding of how students perceive use of social media in classrooms. The focus groups will also help create a survey to be conducted amongst a larger group of students to see how they feel about educators using Social Media in their classrooms. If the results show that students engage more with classroom activities by using Social Media, 
educators should be encouraged to use Social Media as classroom tools to potentially increase student class performance.

\section{$\underline{\text { Methodology }}$}

You will engage in a focus group discussion with 4 other students. The discussion will be mediated by the researcher, Abi John. You will be asked broad and specific questions about your use of Social Media. You will also be asked about your perception about educators using social media in classes. The focus group discussion will be audio recorded. There are specific question that the mediator will ask you, but if the discussion leads to potential probing questions, those questions will be asked as well.

\section{$\underline{\text { Benefits }}$}

This study can help educators by showing a potential way to increase classroom engagement. If students are already engaging with Social Media, then incorporating that as a tool in classrooms could provide a way for students to be more engaged in classrooms and potentially increase student performance.

\section{Compensation}

Students who participated in this focus group will be compensated for their time by being provided extra credit, the amount of which is based on the students' professor.

\section{Confidentiality}

The personal information of the student will be kept private, allowing only for the researcher to access. The information pertaining to the study, (ex: student Social Media use) and any other information shared in the discussion could be published in the final study and wherever the study may be published.

\section{$\underline{\text { Voluntary Participation }}$}

While this experiment is voluntary, you are compensated for your time. You are encouraged to fully participate in this experiment. Your participation can help identify if there is any weight to encourage educators to utilize Social Media in their classrooms. This can be beneficial to both students as well as educators.

You will be made aware of any changes that may occur during the process of this study.

\section{$\underline{\text { Contact Information }}$}

If you have any questions or concerns about this study or if you have any problems arise, please contact Abi John at the University of Louisville at 502-852-1111. If you have any questions or concerns about your rights as a research participant, please contact the University of Louisville Institutional Review Board at 502-852-1112. 


\section{Consent}

I agree to participate in this study: __ YES ___ NO. 


\section{CURRICULUM VITA}

NAME: $\quad$ Abi Mathew John

ADDRESS: Department of Communication

310 Strickler Hall

University of Louisville

Louisville, KY 40292

DOB: $\quad$ Tabuk, Saudi Arabia - August 03, 1993

EDUCATION

\& TRAINING: $\quad$ B.A., Communication

University of Louisville

2011-15 